\title{
New approaches in the diagnosis and treatment of latent tuberculosis infection
}

\author{
Suhail Ahmad
}

\begin{abstract}
With nearly 9 million new active disease cases and 2 million deaths occurring worldwide every year, tuberculosis continues to remain a major public health problem. Exposure to Mycobacterium tuberculosis leads to active disease in only $\sim 10 \%$ people. An effective immune response in remaining individuals stops $M$. tuberculosis multiplication. However, the pathogen is completely eradicated in $\sim 10 \%$ people while others only succeed in containment of infection as some bacilli escape killing and remain in non-replicating (dormant) state (latent tuberculosis infection) in old lesions. The dormant bacilli can resuscitate and cause active disease if a disruption of immune response occurs. Nearly one-third of world population is latently infected with M. tuberculosis and 5\%-10\% of infected individuals will develop active disease during their life time. However, the risk of developing active disease is greatly increased (5\%-15\% every year and $~ 50 \%$ over lifetime) by human immunodeficiency virus-coinfection. While active transmission is a significant contributor of active disease cases in high tuberculosis burden countries, most active disease cases in low tuberculosis incidence countries arise from this pool of latently infected individuals. A positive tuberculin skin test or a more recent and specific interferon-gamma release assay in a person without overt signs of active disease indicates latent tuberculosis infection. Two commercial interferon-gamma release assays, QFT-G-IT and T-SPOT.TB have been developed. The standard treatment for latent tuberculosis infection is daily therapy with isoniazid for nine months. Other options include therapy with rifampicin for 4 months or isoniazid + rifampicin for 3 months or rifampicin + pyrazinamide for 2 months or isoniazid + rifapentine for 3 months. Identification of latently infected individuals and their treatment has lowered tuberculosis incidence in rich, advanced countries. Similar approaches also hold great promise for other countries with low-intermediate rates of tuberculosis incidence.
\end{abstract}

\section{Introduction}

Tuberculosis (TB) is a formidable public health challenge as it contributes considerably to illness and death around the world. The most common causative agent of TB in humans, Mycobacterium tuberculosis, is a member of the M. tuberculosis complex (MTBC) which includes six other closely related species: $M$. bovis, $M$. africanum, M. microti, M. pinnipedii, M. caprae and M. canettii. All MTBC members are obligate pathogens and cause TB; however, they exhibit distinct phenotypic properties and host range. Genetically, MTBC members are closely related, the genome of $M$. tuberculosis shows $>99.9 \%$ similarity with $M$. bovis, the species that primarily infects cattle but can also cause TB in other mammals including man $[1,2]$. The current TB epidemic is being

\footnotetext{
Correspondence: suhail_ah@hsc.edu.kw

Department of Microbiology, Faculty of Medicine, Kuwait University, Kuwait
}

sustained by two important factors; the human immunodeficiency virus (HIV) infection and its association with active TB disease and increasing resistance of $M$. tuberculosis strains to the most effective (first-line) antiTB drugs [3-5]. Other contributing factors include population expansion, poor case detection and cure rates in impoverished countries, wars, famine, diabetes mellitus and social decay and homelessness [6,7].

According to recent estimates, 9.4 million new active disease cases corresponding to an estimated incidence of 139 per 100,000 population occurred throughout the world in 2008 [3,4]. Only 5.7 million of 9.4 million cases of TB (new cases and relapse cases) were notified to national tuberculosis programs of various countries while the rest were based on assessments of effectiveness of surveillance systems. The highest number of TB cases occurred in Asia (55\%) followed by Africa (30\%). The highest incidence rate (351 per 100,000 population) 
was recorded for the African region, mainly due to high prevalence of HIV infection. An estimated 1.4 million (15\%) of incident TB patients were coinfected with HIV in 2008. Globally, the total prevalent TB cases in 2008 were 11.1 million corresponding to 164 cases per 100 000 population that resulted in 1.8 million deaths (including 0.5 million TB patients coinfected with HIV) $[3,4]$. Nearly 440000 cases of multidrug-resistant TB (MDR-TB, defined as infection with $M$. tuberculosis strains resistant at least to the two most important firstline drugs, rifampicin and isoniazid) occurred in 2008 [5]. By 2009, extensively drug-resistant TB (XDR-TB; defined as MDR-TB strains additionally resistant to a fluoroquinolone and a second-line anti-TB injectable agent such as kanamycin, amikacin, or capreomycin) has been found in 58 countries [5]. While MDR-TB is difficult and expensive to treat, XDR-TB is virtually an untreatable disease in most of the developing countries [8].

\section{Establishment and persistence of latent $\boldsymbol{M}$. tuberculosis infection}

Tuberculosis is a communicable disease and infection is initiated by inhalation of droplet nuclei (1-5 $\mu \mathrm{m}$ in diameter particles) containing $M$. tuberculosis, expectorated by patients with active pulmonary or laryngeal TB, typically when the patient coughs. Active transmission occurs more frequently in small households and crowded places in countries with a high incidence of TB and the risk of infection is dependant on several factors such as the infectiousness of the source case, the closeness of contact, the bacillary load inhaled and the host's immune status (Figure 1) [9-11]. Molecular epidemiological studies have shown that there are distinct differences in the disease presentation and population demographics in low TB incidence and high TB incidence countries. In several African and Asian countries, the vast majority of mycobacterial infections are caused by $M$. tuberculosis and incidence rates are highest among young adults, with most cases resulting from recent episodes of infection or reinfection [12-14]. On the contrary, in low TB incidence countries of Western Europe and North America, a higher proportion of active TB cases occur in older patients or among immigrants from high TB incidence countries [12]. Pulmonary TB accounts for $>85 \%$ of active TB cases in high TB incidence countries while extrapulmonary $\mathrm{TB}$ is more common in low TB incidence countries, particularly among HIV infected individuals and immigrants originating from TB endemic countries $[15,16]$.

The inhaled droplet nuclei avoid the defenses of the bronchi due to their small size and penetrate into the terminal alveoli of the lungs where they are engulfed by phagocytic antigen-presenting cells including alveolar macrophages, lung macrophages and dendritic cells. In the lungs, $M$. tuberculosis can also infect non-phagocytic cells in the alveolar space such as endothelial cells, $M$ cells and type 1 and type 2 epithelial cells [17-20]. In the initial phase of infection, $M$. tuberculosis internalized by macrophages and dendritic cells replicates intracellularly and the bacteria-laden immune cells may cross the alveolar barrier to cause systemic dissemination $[18,19]$. The intracellular replication and simultaneous dissemination of the pathogen to the pulmonary lymph nodes and to various other extrapulmonary sites occurs prior to the development of the adaptive immune responses [21,22].

The entry of $M$. tuberculosis in phagocytic immune cells in the alveolar space begins with recognition of pathogen-associated molecular patterns by specific pathogen recognition receptors that initiate a coordinated innate immune response by the host [23]. The $M$. tuberculosis components are recognized by host receptors that include toll-like receptors (TLRs), nucleotidebinding oligomerization domain (NOD)-like receptors (NLRs), and C-type lectins [24-26]. The C-type lectins include mannose receptor (MR), the dendritic cell-specific intercellular adhesion molecule grabbing nonintegrin (DC-SIGN), macrophage inducible C-type lectin (Mincle) and dendritic cell-associated C-type lectin-1 (Dectin-1) [24,27]. The TLR signaling is the main arm of the innate immune response and $M$. tuberculosis internalized through different receptors may also have different fate [28-30].

The M. tuberculosis cell envelope is composed of a cell wall that is covered with a thick waxy mixture of lipids, polysaccharides and mycolic acids. The most important $M$. tuberculosis cell surface ligands that interact with TLRs and other receptors include the 19 and $27 \mathrm{kDa}$ lipoproteins, $38 \mathrm{kDa}$ glycolipoprotein, glycolipids (such as phosphatidylinositol mannoside, PIM; lipomannan, LM; lipoarabinomannan, LAM; and mannosecapped lipoarabinomannan, Man-LAM) and trehalose dimycolate (TDM) (Table 1) [26,28,30,31]. Other ligands may include surface exposed proteins such as LprA and LprG lipoproteins and mammalian cell entry (Mce) proteins encoded by the mce1 and mce3 operons [32-36]. Typically, signals generated through TLR and Mincle promote proinflammatory immune responses while preferential recruitment of DC-SIGN induces suppression and/or exhaustion of immune responses [25,27,30,37]. The glycolipids (such as PIM, LM and, LAM) and lipoproteins (such as $19 \mathrm{kDa}$ lipoprotein, LpqH) that are exposed on $M$. tuberculosis cell surface [38] are mainly recognized by TLR2 (Table 1 ) [24,26,30].

The interaction of $M$. tuberculosis ligand(s) with TLRs initiates an intracellular signaling cascade that culminates in a proinflammatory response (beneficial to the 
Exposure of subjects (contacts of TB patients) to droplet nuclei from a source case of sputum smear-positive pulmonary TB

Duration and intensity of exposure

Host immunologic defenses
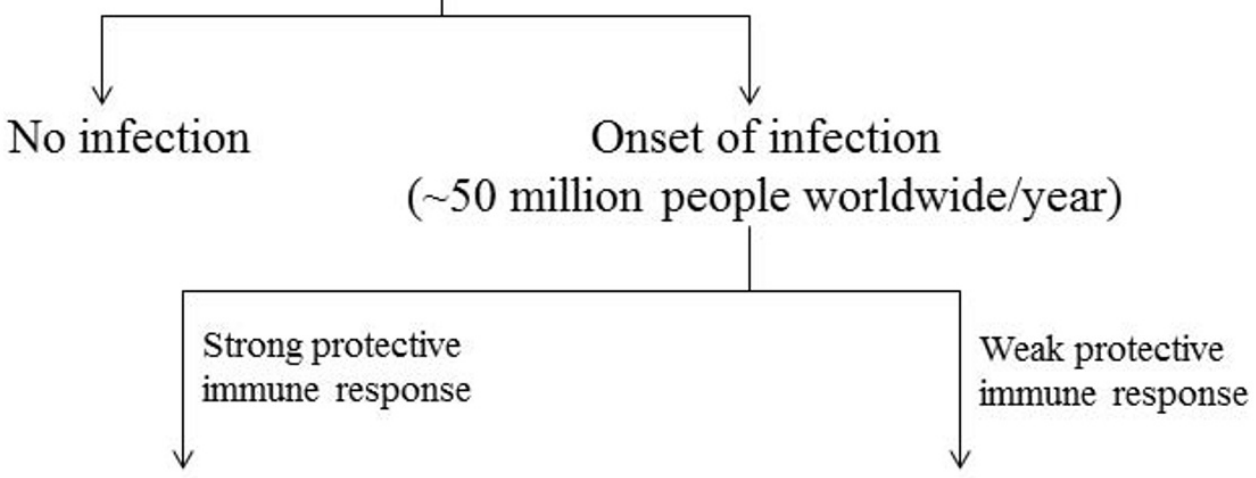

Limited initial bacterial growth

Bacterial growth continues

Host factors, (Primary TB)

Bacterial factors

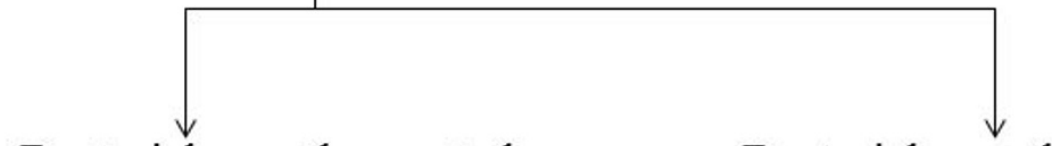

Bacterial growth arrested

Bacterial growth arrested

Pathogen eliminated (10\%)

Some bacilli survive and persist (90\%)

(Sterilizing immunity)

(Latent infection, LTBI)

(Total $\sim 2.2$ billion people in the world)

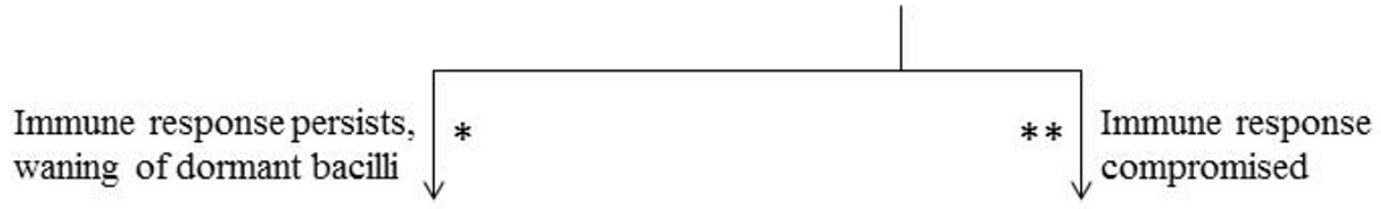

\section{Clearance of \\ latent infection}

Reactivation of
latent infection (Reactivation TB)

Figure 1 Natural progression of events and outcome in an immunocompetent individual following exposure of human subjects (contacts of TB patients) to droplet nuclei containing $M$. tuberculosis expectorated by a source case of sputum smear-positive pulmonary TB. Every year, $\sim 50$ million people worldwide are infected with M. tuberculosis. Complete elimination of tubercle bacilli is achieved in $\sim 10 \%$ individuals only while in $~ 90 \%$ of infected individuals, bacterial growth is stopped but some bacilli survive and persist leading to latent $M$. tuberculosis infection (LTBI). The waning of dormant bacilli in persons with LTBI can be accelerated by therapy with isoniazid for 9 months (denoted by *). The vaccines currently in clinical trials are designed to prevent or delay the reactivation of latent infection in persons with LTBI (denoted by ${ }^{* *}$ ). 
Table 1 Important M. tuberculosis ligands, main receptors on phagocytic immune cells and immune cell processes affected that promote persistence of the pathogen and establishment of latent tuberculosis infection in humans

\begin{tabular}{|c|c|c|c|}
\hline M. tuberculosis ligand ${ }^{a}$ & Host cell receptor $^{b}$ & Immune cell process affected & Reference(s) \\
\hline 19 kDa Lipoprotein (LpqH) & TLR2 & MHC class II expression/antigen presentation & $28,30,90$ \\
\hline 19 kDa Lipoprotein (LpqH) & TLR2 & Phagosomal processing by MHC class I pathway & 89,96 \\
\hline Lipoprotein LprA & TLR2 & MHC class II expression/antigen presentation & 33 \\
\hline Lipoprotein LprG & TLR2 & MHC class II expression/antigen presentation & 32 \\
\hline Phosphatidyinositol mannoside (PIM) & TLR2 & Modulation of macrophage signaling pathways & 26,51 \\
\hline Lipomannan (LM) & TLR2, MR & Modulation of macrophage signaling pathways & 26,51 \\
\hline Lipoarabinomannan (LAM) & TLR2 & Modulation of macrophage signaling pathways & 26,51 \\
\hline Mannose-capped LAM & MR, DC-SIGN & Phagolysosome maturation & 91,92 \\
\hline Mannose-capped LAM & MR, DC-SIGN & MHC class II expression/antigen presentation & $51,91.96$ \\
\hline Mannose-capped LAM & MR, DC-SIGN & IL-12 secretion of dentritic cells/macrophages & 88 \\
\hline Mannose-capped LAM & MR, DC-SIGN & Apoptosis of macrophages & 91,112 \\
\hline Trehalose dimycolate (cord factor) & TLR2, Mincle & Phagolysosome biogenesis & $27,93,95$ \\
\hline Trehalose dimycolate (cord factor) & TLR2, Mincle & MHC class II expression/antigen presentation & $27,94,95$ \\
\hline
\end{tabular}

${ }^{a}$ Mannose-capped LAM, Mannose-capped lipoarabinomannan

${ }^{b}$ TLR2, Toll-like receptor 2; MR, mannose receptor; DC-SIGN, dendritic cell-specific intercellular adhesion molecule grabbing nonintegrin; Mincle, macrophage inducible C-type lectin

host), however, the bacterium has also evolved strategies that can trigger signals that dampen the innate immune response (beneficial to the pathogen). The proinflammatory process results in activation of nuclear transcription factor (NF)- $\kappa \mathrm{B}$ and production of proinflammatory cytokines, chemokines and nitric oxide through either myeloid differentiation primary response protein 88 (MyD88)-dependant or MyD88-independent pathway [24,30,39-41]. A brief outline of the immune response of the host is described here. Several excellent review articles are available for a more detailed description [25,42-45].

In addition to macrophages and dendritic cells, a wide range of other immune components are also involved in an effective immune response against $M$. tuberculosis and include, $\alpha \beta-\mathrm{T}$ cells (both $\mathrm{CD} 4^{+}$and $\mathrm{CD} 8^{+}$), CD1 restricted T cells, $\gamma \delta$-T cells and cytotoxic T cells as well as the cytokines produced by these immune cells $[25,45-47]$. The most important among these are $\mathrm{CD} 4^{+}$ $\mathrm{T}$ cells and the cytokine interferon (IFN)- $\gamma$.

The two major defense mechanisms of macrophages include the fusion of the phagosomes containing $M$. tuberculosis with lysosomes (phagolysosome) that is bactericidal and generation of nitric oxide and other reactive nitrogen intermediates (RNI) which exert toxic effects on the bacilli $[43,45,48-51]$. The $M$. tuberculosis containing phagosomes mature through a series of fusion and fission events with several endocytic vesicles that culminate in a phagolysosome. The fusion-fission events remodel the phagosomal membrane. The $\mathrm{Ca}^{+2}$ signaling cascade and recruitment of vacuolar-proton transporting ATPase $\left(\mathrm{vH}^{+}\right.$-ATPase) cause lowering of internal $\mathrm{pH}$ that allows lysosome-derived acid hydrolases to function efficiently for their microbicidal effect [52-54]. Another mycobactericidal mechanism of macrophages includes lysosomal killing of M. tuberculosis mediated by ubiquitin-derived peptides [55]. The ubiquitination destroys tubercle bacilli by autophagy as a ubiquitin-derived peptide impairs the membrane integrity of $M$. tuberculosis that allows nitric oxide to kill more efficiently. The apoptosis of infected macrophages participates in host defense against infection as apoptotic vesicles containing mycobacterial antigens are taken up by dendritic cells for $\mathrm{CD}^{+} \mathrm{T}$ cell activation by phagosome-enclosed antigens $[25,56,57]$.

Mycobacterial antigens in macrophages or dendritic cells are picked up by the MHC class II molecules and presented to $\mathrm{CD} 4^{+} \mathrm{T}$ cells $[28,32,43]$. The phagosomal membrane is also equipped with the MHC class I processing machinery $[58,59]$. Also, CD1 proteins present glycolipids, lipids, and lipopeptides of lipid-rich $M$. tuberculosis to $\mathrm{T}$ cells $[56,60,61]$. Furthermore, the vesicles formed due to apoptosis of M. tuberculosis-infected macrophages are taken up by dendritic cells and presented to the $\mathrm{T}$ cells through the MHC class I and CD1 molecules [56,61].

Immediately after entry of $M$. tuberculosis, alveolar macrophages produce inflammatory cytokines and chemokines that serve as a signal for infection. The monocytes, neutrophils and lymphocytes migrate to the focal site of infection but they are unable to kill the bacteria efficiently. During this time, the bacilli resist the bactericidal mechanisms of the macrophage (phagolysosome) by preventing phagosome-lysosome fusion, multiply in 
the phagosome and eventually escape from phagosome/ phagolysosome and cause macrophage necrosis [44,51]. The escape of $M$. tuberculosis from phagosome/phagolysosome is aided by the $6-\mathrm{kDa}$ early secreted antigenic target (ESAT-6) protein and ESX-1 protein secretion system encoded by the region of difference 1 (RD1), a genomic segment that is present in all virulent $M$. tuberculosis and $M$. bovis strains but is absent in the vaccine strain $M$. bovis BCG [1,2,62-68]. The ESAT-6 protein associates with liposomes containing dimyristoylphosphatidylcholine and cholesterol and causes destabilization and lysis of liposomes [67]. It has also been shown that ESAT-6, released during acidification of phagosome from ESAT-6:10 kDa-culture filtrate protein (CFP-10) complex (secreted by live $M$. tuberculosis through ESX-1 secretion system), inserts itself into lipid bilayer and causes lysis of phagosome and escape of tubercle bacilli [69]. The ESAT-6 also induces apoptosis of macrophages via the caspase-dependent pathway and cytolysis of type 1 and type 2 alveolar epithelial cells and helps in the dissemination of $M$. tuberculosis [20,70].

The released bacilli multiply extracellularly, are phagocytosed by another macrophage that also fails to control the growth of $M$. tuberculosis and likewise is destroyed $[42,43,51,71,72]$. This progression of events continues unabated (in persons with a weak immune response) leading to active TB disease in $\sim 10 \%$ of individuals (Primary TB) (Figure 1). In vast majority of the infected individuals, however, an effective cell-mediated immune response develops 2-8 weeks after infection as dendritic cells with engulfed bacilli mature, migrate to the regional lymph node and prime $\mathrm{T}$ cells (both $\mathrm{CD}^{+}$and $\mathrm{CD}^{+}$) against $M$. tuberculosis antigens [25,45,73]. The specific immune response produces primed $\mathrm{T}$ cells which migrate back to the focus of infection, guided by the chemokines produced by infected cells. The accumulation of macrophages, $\mathrm{T}$ cells and other host cells (dendritic cells, fibroblasts, endothelial cells and stromal cells) leads to the formation of granuloma at the site of infection $[74,75]$. The $\mathrm{CD}^{+} \mathrm{T}$ cells producing IFN- $\gamma$ recognize infected macrophages presenting antigens from $M$. tuberculosis and kill them $[43,45,76]$.

The early stages of granuloma formation appear to benefit $M$. tuberculosis as ESAT-6 promotes accumulation of macrophages of different activation and maturation stages at the site of infection in which the tubercle bacilli multiply unabated and infected macrophages may also transport the pathogen to other sites in the body $[22,77]$. The eventual formation of solid granuloma due to an effective immune response walls off tubercle bacilli from the rest of the lung tissue, limits bacterial spread and provide microenvironment for interactions among macrophages and other immune cells and the cytokines. It is also apparent now that M. tuberculosis infected individuals show differences in the innate immune responses that lead to the formation of physiologically distinct granulomatous lesions. Some of these lesions eliminate all bacilli (sterilizing immunity) while others allow persistence of viable $M$. tuberculosis in the microenvironment $[75,78]$. Low-dose infection in primate models of human latent TB exhibit at least two types of tuberculous granuloma $[79,80]$. The classic caseous granuloma are composed of epithelial macrophages, neutrophils, and other immune cells surrounded by fibroblasts. M. tuberculosis resides inside macrophages in the central caseous necrotic region that is hypoxic $[80,81]$. The second type of granulomas (fibrotic lesions) are composed of mainly fibroblasts and contain very few macrophages, however, the exact location of viable $M$. tuberculosis in these lesions is not known [80].

With granuloma formation and an effective immune response, most tubercle bacilli are killed and disease progression is halted $[42,45,75]$. Although proinflammatory immune response is generally beneficial to the host, restricting this response is essential to avoid the risk of producing excessive inflammation that could damage host tissues. This is accomplished through a family of receptor tyrosine kinases that provide a negative feedback mechanism to both, TLR-mediated and cytokinedriven proinflammatory immune responses [82,83]. This defense mechanism of the host has been exploited by M. tuberculosis for its survival [84-87]. Several M. tuberculosis factors such as $19-\mathrm{kDa}$ lipoprotein, glycolipids (particularly Man-LAM), trehalose dimycolate (cord factor) and several others (Table 1) can modulate antigenprocessing pathways by MHC class I, MHC class II and CD1 molecules, phagolysosome biogenesis and other macrophage signaling pathways [26-28,30,32,33,88-95]. The suppression of these responses blunt the microbicidal functions of macrophages and other immune cells (such as reactive nitrogen intermediates) or prevent their proper maturation (phagolysosome) $[24,26,30,45,51,96]$.

The inhibition of macrophage responses to $M$. tuberculosis results in a subset of infected macrophages that are unable to present $M$. tuberculosis antigens to $\mathrm{CD}_{4}^{+}$ $\mathrm{T}$ cells. This results in insufficient activation of effector $\mathrm{T}$ cells leading to evasion of immune surveillance and creation of niches where $M$. tuberculosis survives $[45,51,96,97]$. The hypoxia, nutrient deficiency, low $\mathrm{pH}$ and inhibition of respiration by nitric oxide in the microenvironment of the granuloma induce a dormancy program in $M$. tuberculosis $[98,99]$. These conditions transform surviving bacilli into a dormant stage with little or no metabolic and replicative activity, however, expression of DosR-regulated dormancy antigens continues [99-101]. It is also probable that M. tuberculosis, under these conditions, forms spore-like structures, 
typically seen with other mycobacteria in response to prolonged stationary phase or nutrient starvation, for its survival [102]. Decreased outer membrane permeability also protects $M$. tuberculosis from killing by ubiquitinderived peptides [103]. Thus, some non-replicating (resistant) bacilli avoid elimination by the immune system and persist. This latent tuberculosis infection (LTBI) in a person without overt signs of the disease is indicated by the delayed-type hypersensitivity (DTH) response to purified protein derivative (PPD) prepared from culture filtrates of $M$. tuberculosis (tuberculin skin test) $[9,104]$. The dormant bacilli can inhabit the granuloma during the lifetime of the host but are able to resume their growth if (or when) the immune response is compromised (reactivation TB) (Figure 1). The World Health Organization (WHO) has estimated that onethird of the total world population is latently infected with $M$. tuberculosis and 5\%-10\% of the infected individuals will develop active TB disease during their life time [104]. However, the risk of developing active disease is $5 \%-15 \%$ every year and lifetime risk is $~ 50 \%$ in HIV coinfected individuals [3,4,105].

Reactivation of latent infection requires M. tuberculosis to exit dormancy. The lytic transglycosylases known as resuscitation promoting factors and an endopeptidase (RipA) of $M$. tuberculosis have been recognized as vital components for revival from latency [106-108]. Although reactivation of latent infection can occur even decades after initial infection, a person is at greater risk of developing active TB disease during the first two years after infection with $M$. tuberculosis $[9,109,110]$. Several factors can trigger development of active disease from reactivation of remote infection, and typically involve the weakening of the immune system [111]. HIV infection is the most important risk factor for progression to active disease in adults as it causes depletion/ functional abnormalities of $\mathrm{CD}^{+}$and/or $\mathrm{CD}^{+} \mathrm{T}$-cells that are central for protection against active TB disease [3,4,6,105]. Likewise, M. tuberculosis infection accelerates the progression of asymptomatic HIV infection to acquired immunodeficiency syndrome (AIDS) and eventually to death. This is recognized in the current AIDS case definition as pulmonary or extrapulmonary $\mathrm{TB}$ in HIV-infected patient is sufficient for the diagnosis of AIDS. The reactivation TB can occur in any organ system, however, in immunocompetent individuals, it usually occurs in the upper lobes, where higher oxygen pressure supports good bacillary growth.

\section{New dynamic model of latent tuberculosis infection}

The traditional model of LTBI as described in detail above begins with the entry of $M$. tuberculosis in antigen-presenting cells in lung alveoli and the pathogen accomplishes intracellular survival through several evasion strategies including neutralization of the phagosomal $\mathrm{pH}$, antigen presentation by macrophages and dendritic cells that compromise $\mathrm{CD}^{+} \mathrm{T}$ cell stimulation, apoptosis of infected macrophages and interference with autophagy $[51,75,111,112]$. The early stages of developing granuloma benefit the pathogen as it invades macrophages of different activation and maturation stages and thus, survives when the loose aggregates of phagocytes and polymorphonuclear granulocytes transform into a solid granuloma [75,77,111]. Although active disease is averted for the moment, latent infection ensues as the pathogen is not eliminated. The tubercle bacilli are resistant to immune attack as they are transformed into a dormant stage with very low or nil metabolic and replicative activity, however, a dormancy-related gene set called DosR regulon continues to be expressed during latent infection $[99,101]$. The exact physical and metabolic nature and location of persistent tubercle bacilli in the dormant state remains unknown. The bacilli can remain dormant for the entire life of the host without ever causing active disease or they may cause disease several years or even decades later [109,110]. Impaired immunity due to exhaustion or suppression of $\mathrm{T}$ cells results in resuscitation of $M$. tuberculosis from a dormant to a metabolically active stage leading to active TB disease (reactivation TB) $[25,101]$. However, the risk of developing reactivation TB disease is highest during the first two years after infection with $M$. tuberculosis $[109,113]$. Similarly, reactivation TB in immunocompetent individuals immigrating from $\mathrm{TB}$ endemic countries to low TB incidence countries also occurs usually within the first two years of their migration $[6,9,113,114]$. Based on these observations and some recent experimental data, a dynamic model of latent infection has been proposed recently in which endogenous reactivation as well as damage response occurs constantly in immunocompetent individuals [115].

The model suggests that during initial stages (developing granuloma) of infection, $M$. tuberculosis grow well inside phagosome and then escape from phagosome/ phagolysosome and are released in extracellular milieu due to macrophage necrosis $[69,70,116,117]$. Some of the extracellular bacilli stop replicating due to hypoxic and acidic environment, nutrient limitation (conditions that mimic stationary bacterial cultures) and presence of bactericidal enzymes released from destruction of immune cells, even before an effective immune response is fully developed. With the development of an effective immune response, the actively growing bacilli are easily killed, however, the metabolically inactive, non-replicating (dormant) bacilli resist killing and may survive [116].

The model also assigns an important role to foamy macrophages that emerge during chronic inflammatory 
processes (such as TB) due to phagocytosis of cellular debris rich in fatty acids and cholesterol in the dissemination and/or waning of infection. The model suggests that as foamy macrophages phagocytose extracellular non-replicating lipid-rich $M$. tuberculosis along with other cellular debris, the bacilli are not killed due to their non-replicating, metabolically inert (dormant) state. At the same time, tubercle bacilli also do not grow in the intracellular environment as the macrophages are now activated [118-120]. As the foamy macrophages containing non-replicating bacilli drain from lung granuloma towards bronchial tree, they lodge M. tuberculosis into a different region of lung parenchyma due to aerosols generated by inspired air and the bacilli get another chance to begin the infection process at this new location $[115,118,119,121]$. In this infectioncontrol of growth-reinfection process, bacilli getting lodged in the upper lobe may have the chance to cause cavitary lesion. This is due to higher oxygen pressure in upper lobes that can support rapid extracellular bacillary growth resulting in bacillary concentration that can not be controlled by the optimum immune response mounted by the host. The subsequent much stronger inflammatory response leads to tissue destruction, liquefaction and extracellular bacillary growth which amplifies the response further and causes cavitation $[115,116]$.

The dynamic infection model, involving drainage and destruction of non-replicating bacilli in the stomach over a period of time, proposes slow clearance (waning) of latent infection in a sub-set of infected individuals who are not at risk of reinfection. A recent study carried out in Norway, a country with a low risk of active transmission of infection or reinfection, has shown that rates of reactivation $\mathrm{TB}$, among patients previously exposed to $M$. tuberculosis, have progressively declined over the last several years [122]. Furthermore, the prevention of reinfection by bacilli resuscitated from dormancy by isoniazid, during infection-control of growth-reinfection cycles, also explains how therapy for only nine months with a single drug, effective only against actively dividing bacilli, is highly effective for a latent infection sustained by non-replicating bacilli that can presumably survive during the lifetime of the host [115].

\section{Diagnosis of latent $\boldsymbol{M}$. tuberculosis infection}

Despite the fact that control and management of TB in many low TB incidence countries is centered around the identification and subsequent treatment of individuals latently infected with $M$. tuberculosis (LTBI), actual identification of LTBI in human subjects is presently not feasible [123,124]. The current diagnostic tests (such as the tuberculin skin test or more recently developed $\mathrm{T}$ cell-based assays) are only designed to measure the adaptive immune response of the host exposed to $M$. tuberculosis, typically six to eight weeks after exposure to the bacilli [123-126].

The tuberculin skin test (TST) measures cell-mediated immunity in the form of a DTH response to a complex cocktail of $>200 M$. tuberculosis antigens, known as purified protein derivative (PPD) and the test result is usually read as induration (in $\mathrm{mm}$ ) recorded 48 to 72 hours after intradermal injection of PPD [127]. The criteria for a positive TST vary considerably and depend on the inoculum and type of PPD preparation used in the test. In the United States, 5 tuberculin units (TUs) are generally used and the induration of $\geq 5 \mathrm{~mm}$ in HIVseropositive or organ transplant recipient or in a person in contact with a known case of active TB is considered as positive [128]. However, in foreign-born persons originating from high TB incidence countries or persons at higher risk of exposure to $M$. tuberculosis (such as health care professionals), induration of $\geq 10 \mathrm{~mm}$ is regarded as positive TST [128]. In most European countries, 2 TUs are used and the induration of $\geq 10 \mathrm{~mm}$ in immunocompetent adults is considered as positive. In the United Kingdom, 10 TUs are used and the induration of $5-15 \mathrm{~mm}$ in BCG unvaccinated and $\geq 15 \mathrm{~mm}$ in BCG vaccinated immunocompetent adults is considered as positive [123-126]. Skin test reaction over $20 \mathrm{~mm}$ is usually due to active disease; however, a negative skin test in an active TB patient may also result from anergy or incorrect administration of the test or improper storage of the test reagents, thus compromising the sensitivity of the test $[9,104,127,128]$. Skin testing is most suitable for detecting M. tuberculosis infection in developing countries where $>80 \%$ of the global TB cases occur, as it does not require extensive laboratory facilities and health care workers are already familiar with administering and reading skin tests. However, TST has several inherent problems as the antigens present in PPD are also present in the vaccine strain M. bovis BCG and several environmental mycobacteria. Hence, TST has lower specificity as the test can not differentiate between infection with $M$. tuberculosis, prior vaccination with $M$. bovis BCG or sensitization with environmental mycobacteria $[9,104,127,129,130]$. Furthermore, sensitivity of TST is limited in immunocompromised individuals due to anergy. These factors have compromised the sensitivity and specificity of tuberculin skin test for the diagnosis of LTBI.

Highly sensitive and more specific tests for the diagnosis of LTBI have been developed recently as a result of advances in genomics and immunology. The availability of complete genome sequences of $M$. tuberculosis and other Mycobacterium spp. and subtractive hybridization-based approaches identified RD1, a genomic region that is present in all $M$. tuberculosis and pathogenic $M$. bovis strains but is absent in all M. bovis BCG 
vaccine strains and most of the environmental mycobacteria of clinical relevance $[13,64,65]$. Two of the RD1 encoded proteins, ESAT- 6 and CFP-10 are strong T cell antigens $[62,63]$. Early studies in animals showed that DTH skin responses to ESAT-6 and CFP-10 discriminated between animals infected with $M$. tuberculosis from those sensitized to $M$. bovis BCG or environmental mycobacteria [131]. The rESAT-6 obtained from E. coli is also biologically active and was successfully used as a skin test reagent for the diagnosis of tuberculosis infection in humans in phase I clinical trials [132,133]. The sensitivity of rESAT -6 has been enhanced further by combining it with CFP-10 and the ESAT-6/CFP-10 fusion protein was found to be as sensitive as PPD in predicting disease in $M$. tuberculosis-infected guinea pigs [134]. It is expected that rESAT-6/CFP-10 fusion protein could probably replace PPD as skin test reagent for identifying individuals with LTBI.

Other cell mediated immunity-based assays have also been developed. The in vitro T cell-based interferongamma (IFN- $\gamma$ ) release assays (IGRAs) were developed based on the principle that $\mathrm{T}$ cells of individuals sensitized with $M$. tuberculosis antigens produce high levels of IFN- $\gamma$ in response to a reencounter with these antigens [135]. Initially IGRAs used PPD as the stimulating antigen, however, it was subsequently replaced by two M. tuberculosis-specific T cell antigens; ESAT- 6 and CFP-10 and the assays were found to be sensitive and specific for detection of active pulmonary/extrapulmonary TB as well as latent infection [136-140].

Two commercial IGRAs, whole blood, ELISA-based QuantiFERON-TB Gold (Cellestis Ltd., Carnegie, Australia) and peripheral blood mononuclear cell (PBMC) and enzyme-linked immunospot (ELISPOT) technologybased T-SPOT.TB (Oxford Immunotec, Oxford, UK) tests were subsequently developed and approved by Food and Drug Administration (FDA) for detecting latent infection. The first-generation QuantiFERON-TB Gold test was based on stimulation of $\mathrm{T}$ lymphocytes with PPD and measurement of IFN- $\gamma$ production [141]. The enhanced QuantiFERON-TB Gold assay subsequently used ESAT- 6 and CFP-10 proteins as stimulating antigens. The first-generation T-SPOT.TB used ESAT- 6 and CFP-10 proteins as stimulating antigens and detected $\mathrm{T}$ cells themselves [138]. These commercial tests have undergone further improvement since their inception. The newer version of the QuantiFERON-TB Gold assay is called QuantiFERON-TB-Gold-In-Tube (QFT-G-IT) (Cellestis Ltd., Carnegie, Australia) that uses ESAT-6 and CFP-10 and TB7.7 (corresponding to Rv2654 [1]) peptides as antigens. The newer version of T-SPOT.TB also uses peptides of ESAT- 6 and CFP-10 instead of whole ESAT- 6 and CFP-10 proteins as antigens (Oxford Immunotec, Oxford, UK).
The performance of both QFT-G-IT and T-SPOT.TB tests have been evaluated extensively with/without headto-head comparison with TST and several systematic reviews are available for their performance in different settings [123-126,142-144]. Similar to TST, a major limitation of both IGRAs is their inability to distinguish LTBI from active TB disease. This may be particularly important in high $\mathrm{TB}$ incidence countries in which latent infection is widespread and reinfection happens frequently and in immunocompromised individuals (such HIV-seropositive subjects) and children due to subclinical disease presentation [123,124,126]. However, IGRAs have better specificity (higher that TST) as they are not affected by prior BCG vaccination since the antigens used in these assays are not present in $M$. bovis BCG and cross reactivity with environmental mycobacteria is less likely [123-125]. Furthermore, based on limited data in immunocompromised individuals, the sensitivity of IGRAs, particularly for T-SPOT.TB, is also higher than TST [124]. However, the clinical performance of these tests has been variable in different settings around the globe due to differences in spectrum and severity of TB cases and proportion of HIV-coinfected individuals included in various studies $[123,126]$.

In low TB incidence countries, screening for LTBI aims to identify individuals at higher risk of progression from latent infection to active TB disease. These include all recently infected individuals (close contacts of active pulmonary TB index case), recent immigrants from high TB incidence countries and persons with suppressed (such as HIV coinfected) or immature (such as very young children) cellular immune systems [123,126,142]. Previous data on natural history of TB suggest that after exposure to $M$. tuberculosis, 5-10\% of infected individuals develop active TB disease within the first 2 years of initial infection $[109,113]$. In people with a robust immune system, another 5-10\% individuals develop active disease during the remainder of their lives while in immunocompromised individuals, the risk is much higher $[123,124]$. Thus, diagnosis and treatment of LTBI will be most effective if it is specifically directed to those individuals with the highest risk of progression from LTBI to active disease such as recently exposed individuals, young children and HIV-infected and other immunocompromised subjects.

The current cumulative evidence (summarized in several reviews and meta-analyses) [123-126,142-144] suggest that the performance of the two (ELISA-based and ELISPOT-based) formats of IGRAs are nearly comparable in predicting development of active disease in immunocompetent individuals. However, the agreement between IGRAs and TST is generally poor due to falsepositive TST results in BCG vaccinated subjects. The clinical relevance of a positive TST result is usually poor 
(i.e. unable to predict which patients will develop active TB disease in the near future) and sensitivity as well as specificity are influenced by the different cut-off values used in different settings. However, the value of negative TST result in predicting no further development of active disease in human subjects presumably exposed to M. tuberculosis is fairly high (negative predictive value). On the other hand, the predictive value of positive IGRA results for the development of active TB is usually better than that of TST while the predictive value of a negative result is very high in immunocompetent individuals, particularly if the TST is also negative [123-126]. The TST is often negative in immunocompromised individuals and its performance is also influenced by the immunosuppressing conditions while the sensitivity of IGRAs is generally better than TST and the experimental conditions (particularly in T-SPOT.TB assay) can be easily adjusted for testing immunocompromised individuals [124,142].

A major problem associated with IGRAs is the occurrence of indeterminate results that seem to arise mostly due to cellular immune suppression and occur more frequently with the ELISA-based method than with ELISPOT test or discordant results if both, TST and a blood test are performed [123,124]. This is further compounded by the differences that exist in the manner in which these tests are applied for the detection of latently infected individuals in different settings. In the United States and few other countries, national guidelines advocate up-front use of a blood test (IGRA) as a direct replacement for TST in all groups of subjects [145]. Due to higher sensitivity of IGRAs, it is likely that some individuals who are positive for a blood test but who may have been TST negative (if the test was performed) are unnecessarily treated. On the contrary, in the United Kingdom and other European countries, initial screening is performed with TST except in individuals in whom TST is unreliable (young children, HIV-seropositive and other immunosuppressed individuals) [124,146]. For the latter grouping and for TST-positive individuals at higher risk of developing active disease, a blood test is recommended for confirmation of a presumed infection. Thus, it is also probable that a TST-negative subject who may have been IGRA positive will not be identified as having LTBI and will, therefore, not receive treatment. Consequently this apoproach, though supposedly more economical, may result in undertreatment of some individuals with LTBI $[123,124]$. A discordant result (TST negative but IGRA positive) in an immunocompetent individual should be repeated after 3 months and should be treated for LTBI if IGRA still remains positive (a negative IGRA on repeat testing may signify a transient M. tuberculosis infection that was quickly cleared) [124]. However, a similar result in an immunocompromised individual should be carefully evaluated as in this setting, any positive result may be significant.

Although both, TST and IGRAs cannot distinguish between LTBI and active TB disease in immunocompetent adults $[123,126]$, however, in high-risk individuals with immunosuppressive conditions and children, IGRAs may help in the investigation of active disease as adjunctive diagnostic tests, particularly if specimens (such as bronchoalveolar lavage, cerebrospinal fluid) from the suspected site of infection rather than blood is used for the diagnostic assay [147-149]. While the results of IGRAs exhibit better correlation with surrogate measures of exposure to $M$. tuberculosis in low TB incidence countries, however, their performance is generally sub-optimal in countries with a high TB incidence [123-126,143,144,150]. Application of targeted tuberculin skin testing and IGRAs to identify latently infected individuals and their treatment for LTBI has greatly helped in lowering the incidence of TB in rich, advanced countries [128,138,140,144,151]. Previous studies have shown that majority of active disease cases in low or low-intermediate incidence countries in immigrants/ expatriates originating from TB endemic countries occur as a result of reactivation of previously acquired infection mostly within two years of their migration $[6,9,113,114,140]$. Some other low-intermediate TB incidence countries which contain large expatriate populations originating from TB endemic countries are also evolving similar strategies for controlling TB [152-157].

Another variation of conventional cell mediated immunity-based assays (IGRAs) has also been developed by using flow cytometry [158]. Although flow cytometric approach uses smaller blood volume $(<1 \mathrm{ml})$, the assay will have limited utility in much of the developing world due to the high cost of flow cytometers and the need for technically experienced personnel. The detection of significant levels of antibodies to some M. tuberculosisspecific proteins has also been noted in contacts of TB patients (latently infected individuals) as well as in patients with active TB disease but not in healthy subjects [159-162]. However, antibody-based methods are only experimental and are not used in clinical practice for the detection of LTBI.

\section{Treatment of latent $\boldsymbol{M}$. tuberculosis infection}

Tracing contacts of infectious pulmonary TB cases (sputum smear-positive) for exposure to tubercle bacilli leading to latent $M$. tuberculosis infection (LTBI) and treatment of latently-infected individuals at high risk of progressing from latent infection to active disease has proven extremely effective in the control of TB in the United States and other low TB-burden countries $[128,151,163]$. Treatment of LTBI in infected persons substantially reduces the likelihood of activation of 
dormant infection and subsequent development of active TB disease (Figure 1). The American Thoracic Society (ATS) and Centers for Disease Control and Prevention (CDC) issued guidelines in 2000 for the treatment of LTBI which were also endorsed by the Infectious Diseases Society of America and American Academy of Pediatrics [128]. An update to these guidelines was published in 2005 that also included recommendations for pediatric subjects [164]. The treatment options currently available for LTBI are summarized in Table 2.

The standard regimen for the treatment of LTBI in United States and Canada is daily self-administered therapy with isoniazid (INH) for nine months based on clinical trial data but the duration of treatment can be reduced to 6 months for adults seronegative for HIVinfection $[128,164]$. The International Union Against Tuberculosis (IUAT) recommends daily therapy with INH for 12 months as it is more effective than the 6month course (75\% vs. 65\%) [165]. The preferred duration of treatment for most patients with LTBI in the United States and European countries is 9 months since clinical trial data showed that the efficacy of 6-month regimen is reduced to $60 \%$ while 12 -month regimen is advocated for individuals at higher risk of developing active disease $[123,166]$. According to the CDC guidelines, the frequency can also be reduced from daily therapy to twice weekly therapy with increased dosage of INH, however, the twice weekly regimen must be given as directly observed treatment (DOT) [164]. Inclusion of DOT adds a substantial additional expense to the treatment strategies. The efficacy of INH treatment in preventing active $\mathrm{TB}$ exceeds $90 \%$ among persons who complete treatment [165]. However, the overall effectiveness of these regimens is severely limited as the completion rates in clinical settings have been rather low, ranging from $30 \%$ to $64 \%$ only [167-169]. Completion rates in other settings have been even lower [170].
Although INH is tolerated fairly well by most of the individuals, there is a risk of hepatic toxicity in selected populations. Studies have shown that $10 \%$ to $22 \%$ of participants taking INH for LTBI have at least one episode of elevated serum transaminase levels. Although the rates of clinically significant hepatitis were much lower $(<2 \%)$, the risk and severity increased with age and concomitant alcohol consumption [171-173]. INH can also cause peripheral neuropathy but the risk can be lowered by concomitant use of pyridoxine (vitamin B6) [174]. Poor adherence due to the long duration of treatment and concerns for hepatotoxicity in selected patient populations resulted in development of shorter and more effective treatment options for LTBI [128,164].

The ATS and CDC guidelines also included 4 months of rifampicin (RMP) alone or 2 months of RMP and pyrazinamide (PZA) as acceptable alternatives for the treatment of LTBI [128]. The RMP alone is recommended for persons intolerant to INH, close contacts of TB cases in which the isolate of M. tuberculosis is resistant to INH or INH resistance is suspected due to the origin of foreign-born persons from countries where INH resistance rates are high $[128,175,176]$. There are several advantages with 4 month daily therapy with RMP such as lower cost, higher adherence to treatment and fewer adverse reactions including hepatotoxicity [151,169,177-180]. However, treatment with RMP alone is not recommended for HIV-seropositive persons on concomitant anti-retroviral therapy as this may lead to the development of acquired rifamycin resistance $[164,181,182]$. Furthermore, active disease in an HIVinfected individual should be ruled out first since monodrug therapy in an undiagnosed active TB disease case may also lead to RMP resistance. However, active TB disease is more difficult to exclude in HIV-infected individuals as they are less likely to have typical features of pulmonary TB and extrapulmonary TB occurs more

Table 2 Currently available drug regimens for the treatment of latent tuberculosis infection

\begin{tabular}{cccccc}
\hline Drug(s) & $\begin{array}{c}\text { Adult maximum } \\
\text { dose(s) }(\mathbf{m g})\end{array}$ & Duration of treatment & Drug intake & Frequency & Comments \\
\hline INH & 300 & 9 months & Self administered & Daily & Preferred regimen by CDC \\
\hline INH & 900 & 9 months & Under DOT & 2/Wk & Alternative regimen \\
\hline INH & 300 & 6 months & Self administered & Daily & For HIV seronegative only \\
\hline INH & 900 & 6 months & Under DOT & 2/Wk & For HIV seronegative only \\
\hline INH & 300 & 12 months & Self administered & Daily & Preferred regimen by IUAT \\
\hline RMP & 600 & 4 months & Self administered & Daily & For LTBI with INH strain in HIV seronegative subjects \\
\hline INH + RMP & $300+600$ & 3 months & Self administered & Daily & Good alternative option \\
\hline RMP + PZA & $600+2000$ & 2 months & Self administered & Daily & Higher risk of hepatotoxicity \\
\hline RMP + PZA & $600+2500$ & 2 months & Under DOT & 2/Wk & Higerh risk of hepatotoxicity \\
\hline INH + RPE & $900+900$ & 3 months & Under DOT & 1/Wk & Promising option
\end{tabular}

INH, isoniazid; RMP, rifampicin; PZA, pyrazinamide; RPE, rifapentine; DOT, directly observed treatment; $2 /$ Wk, twice weekly; $1 /$ Wk, once weekly; CDC, Center for Disease Control and Prevention; HIV, human immunodeficiency virus; IUAT, international Union Against Tuberculosis; LTBI, latent tuberculosis infection 
frequently $[6,183,184]$. The regimen of RMP alone is also not suitable for patients with other underlying conditions such as diabetes $[185,186]$.

Treatment of LTBI with RMP + PZA for 4 months is another alternative choice that was advocated by ATS and CDC guidelines in 2000 [128]. Although initial studies with 2 months of RMP + PZA in HIV-infected persons were reported to be as effective and safe as INH treatment $[187,188]$, several cases of severe liver injury and/or death were reported subsequently with the RMP + PZA regimen resulting in revision of ATS/CDC recommendations in 2003 [189]. The revised guidelines advocated that 2 months of RMP + PZA regimen should not generally be offered to HIV-seronegative or HIVseropositive individuals $[163,164]$. A meta-analysis involving six clinical trials comparing the effectiveness of 2 months of RMP + PZA with 6 or 12 months of INH treatment showed that RMP + PZA regimen was associated with increased risk of hepatotoxicity in HIV seronegative persons while the results for HIV-infected persons were inconclusive [190]. However, when the results of 2 months of RMP + PZA were compared with 6 months of INH treatment without supplementation with pyridoxine in HIV-infected persons, the data showed no significant differences in hepatotoxicity in the two sub-groups. The results of some studies suggest that 2 months of RMP + PZA regimen may also be considered when other regimens are unsuitable and monitoring of liver function tests is feasible [191,192].

Other options that have been tested or are under evaluation for the treatment of LTBI include 3 months of $\mathrm{INH}+\mathrm{RMP}$ given daily or twice weekly under DOT and 3 months of INH + rifapentin (RPE) given once weekly. The 3 months of INH + RMP regimen has been tested mostly in the United Kingdom. A meta-analysis of five studies carried out in both HIV-infected and HIV-seronegative individuals as well as two subsequent studies have shown that the 3 month of INH + RMP treatment is well tolerated and is as effective and safe as 6 to 12 months of INH treatment alone [193-195]. The longer half life of RPE, approved by U. S. Food and Drug Administration (FDA) in 1998 for the treatment of $\mathrm{TB}$, has allowed once weekly dosing of INH + RPE for the treatment of LTBI [196]. One small study comparing once-weekly INH + RPE for 3 months with daily RMP + PZA for 2 months reported fewer discontinuation of treatment due to hepatotoxicity in the INH + RPE arm compared to the RMP + PZA arm even though the risk of developing active TB was nearly same in both the groups [197]. A large multi-center study is currently being conducted by the Tuberculosis Trials Consortium of the CDC to determine the efficacy of once weekly dosing of INH + RPE in preventing active disease among high-risk individuals with LTBI. However, the cost of once weekly regimen of INH + RPE is an important issue since RPE is currently more expensive than RMP.

\section{Future prospects}

A major concern that has arisen recently is the threat of latent infection in a person exposed to a source case infected with multidrug-resistant strain of $M$. tuberculosis (MDR-TB). As nearly 440000 cases of MDR-TB corresponding to nearly $5 \%$ of all incident $\mathrm{TB}$ cases occurred in 2008 [5], this concern is likely to attract greater attention in the near future. Only scant information is available in this setting as there have been no randomized controlled trials to assess the effectiveness of specific regimens [198]. A 6 to 12 month regimen of a fluoroquinolone + pyrazinamide or ethambutol + pyrazinamide is recommended by CDC. However, the effectiveness and optimal duration of these regimens is largely unknown as they are very poorly tolerated [199]. The newer drugs that are in different stages of development may offer better alternatives for the treatment of both, active TB disease as well as LTBI.

The new generation fluoroquinolones such as moxifloxacin have excellent (bactericidal) activity against $M$. tuberculosis and may be more effective in the treatment of LTBI than older drugs of the same class [200,201]. In experimental animal model of latent infection, the once weekly regimen of rifapentine + moxifloxacin for 3 months was found to be as effective as daily therapy with isoniazid for 9 months [202]. The PA-824, a nitroimidazo-oxazine, is another promising compound that is active against MDR-TB strains and is also active against non-replicating persistent bacteria, making it an ideal drug candidate for the treatment of LTBI. The treatment regimen containing PA-824, moxifloxacin, and pyrazinamide was highly effective in murine model of tuberculosis [203]. The OPC-67683, a nitroimidazo-oxazone, is another promising new compound that shows promising results against tuberculosis in mice [204]. A diarylquinoline (R207910 also known as TMC207) has shown more potent early bactericidal activity than INH during early phase of infection and higher bactericidal activity late in infection than RMP alone and thus may provide another option for the treatment of LTBI $[205,206]$. Another promising drug is SQ109 (1,2-ethylenediamine) that is structurally related to ethambutol but is more potent [207,208]. It is expected that some of these new drugs will provide additional options for the treatment of LTBI in the near future.

Another approach that is actively being pursued for controlling development of active disease in persons with LTBI is development of novel vaccines that may prevent $\mathrm{TB}$ disease reactivation by efficiently containing the pathogen in a latent state in infected individuals 
[209-211]. More than 10 vaccine candidates have entered clinical trials in the past few years [209]. Two of these vaccine candidates are recombinant $M$. bovis BCG constructs designed to improve the antigenicity and/or immunogenicity of the current BCG vaccine [212,213]. Another seven subunit vaccines are being tested in clinical trials and are being used as booster vaccines designed to reorient the immune response after priming with recombinant BCG vaccines. Three of the subunit vaccines are incorporated in viral carriers while the other four subunit vaccines are being delivered through adjuvant formulations [209,214-216]. The recombinant BCG and booster subunit vaccines are designed to be given prior to $M$. tuberculosis infection to sustain latent infection and either prevent or delay the reactivation of latent infection by inducing a memory $\mathrm{T}$ cell response that resists exhaustion and suppression [209]. Other vaccine candidates under development include further modifications such as inclusion of dormancy-regulated genes to improve the efficacy of BCG replacement vaccine candidates for post-exposure vaccination of latently infected individuals (Figure 1) [101,209]. A drawback of the above vaccines is that they prevent or delay the reactivation of dormant infection but do not eradicate the pathogen. However, attempts are now underway to combine the antigens of metabolically active (such as secreted proteins) and dormant (such as dormancyregulated genes) state of $M$. tuberculosis in both, the recombinant BCG and subunit booster vaccines to achieve sterile eradication of the pathogen [209].

\section{Conclusion}

Infection with $M$. tuberculosis begins with the phagocytosis of tubercle bacilli by antigen-presenting cells in human lung alveoli. This sets in motion a complex infection process by the pathogen and a potentially protective immune response by the host. M. tuberculosis has devoted a large part of its genome towards functions that allow it to successfully establish progressive or latent infection in majority of infected individuals. The failure of immune-mediated clearance is due to multiple strategies adopted by $M$. tuberculosis that blunt the microbicidal mechanisms of infected immune cells and formation of distinct granulomatous lesions that differ in their ability to suppress or support the persistence of viable $M$. tuberculosis (LTBI). A positive tuberculin skin test or $\mathrm{T}$ cell-based interferon- $\gamma$ release assay in a person with no overt signs of active disease indicates LTBI and requires treatment of individuals particularly those at the highest risk of progression from LTBI to active disease such as recently exposed individuals, young children and HIV-infected and other immunocompromised subjects. Standard treatment regimen for LTBI is daily therapy with isoniazid for nine months. New drugs/drug combinations as well as novel vaccine approaches are being developed for eradication of latent infection in exposed individuals. Identification and treatment of latently infected individuals has greatly helped in control of $\mathrm{TB}$ in rich, advanced countries and similar approaches hold great promise for other countries with low-intermediate rates of TB incidence.

Acknowledgements

This study was supported by Kuwait University Research Administration grant Ml 05/00.

\section{Competing interests}

The author declares that they have no competing interests.

Received: 14 September 2010 Accepted: 3 December 2010 Published: 3 December 2010

\section{References}

1. Cole ST, Brosch R, Parkhill J, Garnier T, Churcher C, Harris D, Gordon SV, Eiglmeier K, Gas S, Barry CE, Tekaia F, Badcock K, Basham D, Brown D, Chillingworth T, Connor R, Davies R, Devlin K, Feltwell T, Gentles S, Hamlin N, Holroyd S, Hornsby T, Jagels K, Krogh A, McLean J, Moule S, Murphy L, Oliver K, Osborne J, Quail MA, Rajandream MA, Rogers J, Rutter S, Seeger K, Skelton J, Squares R, Squares S, Sulston JE, Taylor K, Whitehead S, Barrell BG: Deciphering the biology of Mycobacterium tuberculosis from the complete genome sequence. Nature 1998, 393:537-544.

2. Garnier T, Eiglmeier K, Camus JC, Medina N, Mansoor H, Pryor M, Duthoy S, Grondin S, Lacroix C, Monsempe C, Simon S, Harris B, Atkin R, Doggett J, Mayes R, Keating L, Wheeler PR, Parkhill J, Barrell BG, Cole ST, Gordon SV, Hewinson RG: The complete genome sequence of Mycobacterium bovis. Proc Natl Acad Sci USA 2003, 100:7877-7882.

3. World Health Organization: Global tuberculosis control: surveillance, planning and financing. WHO report 2009. WHO/HTM/TB/2009.411 Geneva, Switzerland: WHO; 2009

4. World Health Organization: Global tuberculosis control: a short update to the 2009 report. WHO/HTM/TB/2009.426 Geneva, Switzerland: WHO; 2009.

5. World Health Organization: Multidrug and extensively drug-resistant TB (M/XDR-TB): 2010 global report on surveillance and response. WHO/HTM/ TB/2010.3 Geneva, Switzerland: WHO; 2010.

6. Harries AD, Dye C: Tuberculosis. Ann Trop Med Parasitol 2006, 100:415-431.

7. Dooley K, Chaisson RE: Tuberculosis and diabetes mellitus: convergence of two epidemics. Lancet Infect Dis 2009, 9:737-746.

8. Ahmad S, Mokaddas E: Recent advances in the diagnosis and treatment of multidrug-resistant tuberculosis. Resp Med 2009, 103:1777-1790.

9. Frieden TR, Sterling TR, Munsiff SS, Watt CJ, Dye C: Tuberculosis. Lancet 2003, 362:887-899.

10. Hill PC, Brookes RH, Fox A, Fielding $K$, Jeffries DJ, Jackson-Sillah D, Lugos MD, Owiafe PK, Donkor SA, Hammond AS, Otu JK, Corrah T, Adegbola RA, McAdam KP: Large scale evaluation of enzyme-linked immunospot assay and skin test for diagnosis of Mycobacterium tuberculosis infection against a gradient of exposure in The Gambia. Clin Infect Dis 2004, 38:966-973.

11. Bellamy R: Genetic susceptibility to tuberculosis. Clin Chest Med 2005, 26:233-246.

12. Dye C: Global epidemiology of tuberculosis. Lancet 2006, 367:938-940.

13. Mathema B, Kurepina N, Fallows D, Kreisworth BN: Lessons from molecular epidemiology and comparative genomics. Semin Resp Crit Care Med 2008, 29:467-480.

14. Mokaddas E, Ahmad S: Species spectrum of nontuberculous mycobacteria isolated from clinical specimens in Kuwait. Curr Microbiol 2008, 56:413-417.

15. Golden MP, Vikram HR: Extrapulmonary tuberculosis: an overview. Am Fam Phys 2005, 72:1761-1768.

16. Mokaddas E, Ahmad S, Samir I: Secular trends in susceptibility patterns of Mycobacterium tuberculosis isolates in Kuwait, 1996-2005. Int J Tuberc Lung Dis 2008, 12:319-325. 
17. Bermudez LE, Goodman J: Mycobacterium tuberculosis invades and replicates within type II alveolar cells. Infect Immun 1996, 64:1400-1406.

18. Teitelbaum R, Schubert W, Gunther L, Kress Y, Macaluso F, Pollard JW, McMurray DN, Bloom BR: The M cell as a portal of entry to the lung for the bacterial pathogen Mycobacterium tuberculosis. Immunity 1999, 10:641-650.

19. Bermudez LE, Sangari FJ, Kolonoski $P$, Petrofski M, Goodman J: The efficiency of Mycobacterium tuberculosis across a bilayer of epithelial and endothelial cells as a model of the alveolar wall is a consequence of transport within mononuclear phagocytes and invasion of alveolar epithelial cells. Infect Immun 2002, 70:140-146.

20. Kinhikar AG, Verma I, Chandra D, Singh KK, Weldingh K, Andersen P, Hsu T, Jacobs WR Jr, Laal S: Potential role for ESAT6 in dissemination of Mycobacterium tuberculosis via human lung epithelial cells. Mol Microbiol 2010, 75:92-106.

21. Chackerian AA, Alt JM, Perera TV, Dascher CC, Behar SM: Dissemination of Mycobacterium tuberculosis is influenced by host factors and precedes the initiation of T-cell immunity. Infect Immun 2002, 70:4501-4509.

22. Davis JM, Ramakrishnan L: The role of the granuloma in expansion of early tuberculous infection. Cell 2009, 136:37-49.

23. Akira S, Uematsu S, Takeuchi O: Pathogen recognition and innate immunity. Cell 2006, 124:783-801.

24. Jo E-K: Mycobacterial interaction with innate receptors: TLRs, C-type lectins, and NLRs. Curr Opin Infect Dis 2008, 21:279-286.

25. Dorhoi A, Kaufmann SH: Fine-tuning of $\mathrm{T}$ cell responses during infection. Curr Opin Immunol 2009, 21:367-377.

26. Harding CV, Henry Boom W: Regulation of antigen presentation by Mycobacterium tuberculosis: a role for toll-like receptors. Nat Rev Microbiol 2010, 8:296-307.

27. Ishikawa E, Ishikawa T, Morita YS, Toyonaga K, Yamada H, Takeuchi O, Kinoshita T, Akira S, Yoshikai Y, Yamasaki S: Direct recognition of the mycobacterial glycolipid, trehalose dimycolate, by C-type lectin Mincle. J Exp Med 2009, 206:2879-2888.

28. Noss EH, Pai RK, Sellati TJ, Radolf JD, Belisle J, Golenbock DT, Boom WH, Harding CV: Toll-like receptor 2-dependant inhibition of macrophage class II MHC expression and antigen processing by $19 \mathrm{kD}$ lipoprotein of Mycobacterium tuberculosis. J Immunol 2001, 167:910-918.

29. Yang CS, Lee JS, Song CH, Hur GM, Lee SJ, Tanaka S, Akira S, Paik TH, Jo EK: Protein kinase $C$ zeta plays an essential role for Mycobacterium tuberculosis-induced extracellular signal-regulated kinase 1/2 activation in monocytes/macrophages via Toll-like receptor 2. Cell Microbiol 2007, 9:382-396.

30. Jo EK, Yang CS, Choi CH, Harding CV: Intracellular signaling cascades regulating innate immune responses to mycobacteria: branching out from Toll-like receptors. Cell Microbiol 2007, 9:1087-1098.

31. Jung SB, Yang CS, Lee JS, Shin AR, Jung SS, Son JW, Harding CV, Kim HJ, Park JK, Paik TH, Song CH, Jo EK: The mycobacterial 38-kilodalton glycolipoprotein antigen activates the mitogen-activated protein kinase pathway and release of proinflammatory cytokines through Toll-like receptors 2 and 4 in human monocytes. Infect Immun 2006, 74:2686-2696.

32. Gehring AJ, Dobos KM, Belisle JT, Harding CV, Boom WH: Mycobacterium tuberculosis LprG (Rv1411c): a novel TLR2 ligand that inhibits human macrophage class II antigen processing. J Immunol 2004, 173:2660-2668.

33. Pecora ND, Gehring AJ, Canaday DH, Boom WH, Harding CV: Mycobacterium tuberculosis LprA is a lipoprotein agonist of TLR2 that regulates innate immunity and APC function. J Immunol 2006, 177:422-429.

34. Chitale S, Ehrt S, Kawamura I, Fujimura T, Shimono N, Anand N, Lu S, Cohen-Gould L, Riley LW: Recombinant Mycobacterium tuberculosis protein associated with mammalian cell entry. Cell Microbiol 2001, 3:247-254

35. Ahmad S, El-Shazly S, Mustafa AS, Al-Attiyah R: The six mammalian cell entry proteins (Mce3A-F) encoded by the mce3 operon are expressed during in vitro growth of Mycobacterium tuberculosis. Scand J Immunol 2005, 62:16-24.

36. El-Shazly S, Ahmad S, Mustafa AS, Al-Attiyah R, Krajci D: The internalization of latex beads coated with mammalian cell entry (Mce) proteins encoded by mce3 operon of Mycobacterium tuberculosis by HeLa cells. J Med Microbiol 2007, 56:1145-1151.
37. Dennehy KM, Willment JA, Williams DL, Brown GD: Reciprocal regulation of IL-23 and IL-12 following co-activation of Dectin-1 and TLR signaling pathways. Eur J Immunol 2009, 39:1379-1386.

38. Sani M, Houben EN, Geurtsen J, Pierson J, de Punder K, van Zon M, Wever B, Piersma SR, Jiménez CR, Daffé M, Appelmelk BJ, Bitter W, van der Wel N, Peters PJ: Direct visualization by cryo-EM of the mycobacterial capsular layer: a labile structure containing ESX-1-secreted proteins. PLoS Pathog 2010, 6:e1000794.

39. Hoebe K, Du X, Georgel P, Janssen E, Tabeta K, Kim SO, Goode J, Lin P, Mann N, Mudd S, Crozat K, Sovath S, Han J, Beutler B: Identification of Lps2 as a key transducer of MyD88-independent TLR signalling. Nature 2003, 424:743-748

40. Yamamoto M, Sato S, Hemmi H, Hoshino K, Kaisho T, Sanjo H, Takeuchi O, Sugiyama M, Okabe M, Takeda K, Akira S: Role of adaptor TRIF in the MyD88-independent toll-like receptor signaling pathway. Science 2003, 301:640-643.

41. Xu Y, Jagannath C, Liu XD, Sharafkhaneh A, Kolodziejska KE, Eissa NT: Tolllike receptor 4 is a sensor for autophagy associated with innate immunity. Immunity 2007, 27:135-144.

42. Tufariello JM, Chan J, Flynn JL: Latent tuberculosis: mechanisms of host and bacillus that contribute to persistent infection. Lancet Infect Dis 2003, 3:578-590.

43. Chan J, Flynn J: The immunological aspects of latency in tuberculosis. Clin Immunol 2004, 110:2-12.

44. Kusner DJ: Mechanisms of mycobacterial persistence in tuberculosis. Clin Immunol 2005, 114:239-247.

45. Cooper AM: Cell-mediated immune responses in tuberculosis. Annu Rev Immunol 2009, 27:393-422.

46. Scanga CA, Mohan VP, Yu K, Joseph H, Tanaka K, Chan J, Flynn JL: Depletion of CD4 T-cells causes reactivation of murine persistent tuberculosis despite continued expression of interferon- $\gamma$ and nitric oxide synthase. J Exp Med 2000, 192:347-358.

47. Beetz S, Wesch D, Marischen L, Welte S, Oberg HH, Kabelitz D: Innate immune functions of human $\gamma \delta$ T cells. Immunobiology 2008, 213:173-182

48. Chan J, Xing Y, Magliozzo RS, Bloom BR: Killing of virulent Mycobactrium tuberculosis by reactive nitrogen intermediates produced by activated murine macrophages. J Exp Med 1992, 175:1111-1112.

49. Scanga CA, Mohan VP, Tanaka K, Alland D, Flynn JL, Chan J: The inducible nitric oxide synthase locus confers protection against aerogenic challenge of both clinical and laboratory strains of Mycobacterium tuberculosis in mice. Infect Immun 2001, 69:7711-7717.

50. Rhode K, Yates RM, Purdy GE, Russell DG: Mycobactrium tuberculosis and the environment within the phagosome. Immunol Rev 2007, 219:37-54.

51. Pieters J: Mycobacterium tuberculosis and the macrophage: maintaining a balance. Cell Host Microbe 2008, 3:399-407.

52. Sturgill-Koszycki S, Schlesinger PH, Chakraborty P, Haddix PL, Collins HL, Fok AK, Allen RD, Gluck SL, Heuser J, Russell DG: Lack of acidification in Mycobacterium phagosomes produced by exclusion of the vesicular proton-ATPase. Science 1994, 263:678-681.

53. Yates RM, Hermetter A, Russell DG: The kinetics of phagosome maturation as a function of phagosome/lysosome fusion and acquisition of hydrolytic activity. Traffic 2005, 6:413-420.

54. Yadav M, Clark L, Schorey JS: Macrophage's proinflammatory response to a mycobacterial infection is dependant on sphingosine kinase-mediated activation of phosphatidylinositol phospholipase C, protein kinase C, ERK1/2, and phosphatidylinositol 3-kinase. J Immunol 2006 176:5494-5503

55. Alonso S, Pethe K, Russell DG, Purdy GE: Lysosomal killing of Mycobacterium tuberculosis mediated by ubiquitin-derived peptides is enhanced by autophagy. Proc Natl Acad Sci USA 2007, 104:6031-6036.

56. Schaible UE, Winau F, Sieling PA, Fischer K, Collins HL, Hagens K, Modlin RL, Brinkmann V, Kaufmann SH: Apoptosis facilitates antigen presentation to T lymphocytes through MHC-1 and CD1 in tuberculosis. Nat Med 2003, 9:1039-1046

57. Winau F, Weber S, Sad S, de Diego J, Hoops SL, Breiden B, Sandhoff K, Brinkmann V, Kaufmann SHE, Schaible UE: Apoptotic vesicles crossprime CD8 T cells and protect against tuberculosis. Immunity 2006, 24:105-117.

58. Guermonprez P, Saveanu L, Kleijmeer M, Davoust J, Van Endert P, Amigorina S: ER-phagosome fusion defines an MHC class I crosspresentation compartment in dendritic cells. Nature 2003, 425:397-402. 
59. Houde M, Bertholet S, Gagnon E, Brunet S, Goyette G, Laplante A Princiotta MF, Thibault P, Sacks D, Desjardins M: Phagosomes are competent organelles for antigen cross-presentation. Nature 2003, 425:402-406.

60. Kang SJ, Cresswell P: Saposins facilitate CD1d-restricted presentation of an exogenous lipid antigen to T cells. Nat Immunol 2004, 5:175-181.

61. Barral DC, Brenner MB: CD1 antigen presentation: how it works. Nat Rev Immunol 2007, 7:929-941.

62. Harboe M, Oettinger T, Wiker HG, Rosenkrands I, Andersen P: Evidence for occurrence of the ESAT-6 protein in Mycobacterium tuberculosis and virulent Mycobacterium bovis and for its absence in Mycobacterium bovis BCG. Infect Immun 1996, 64:16-22

63. Berthet FX, Rasmussen PB, Rosenkrands I, Andersen P, Gicquel B: A Mycobacterium tuberculosis operon encoding ESAT-6 and a novel lowmolecular-mass culture filtrate protein (CFP-10). Microbiology 1998, 144:3195-3205.

64. Behr MA, Wilson MA, Gill WP, Salamon H, Schoolnik GK, Rane S, Small PM: Comparative genomics of BCG vaccines by whole-genome DNA microarray. Science 1999, 284:1520-1523.

65. Gordon SV, Brosch R, Billault A, Garnier T, Eiglmeier K, Cole ST: Identification of variable regions in the genomes of tubercle bacilli using bacterial artificial chromosome arrays. Mol Microbiol 1999, 32:643-655.

66. Guinn KM, Hickey MJ, Mathur SK, Zakel KL, Grotzke JE, Lewinsohn DM, Smith S, Sherman DR: Individual RD1-region genes are required for export of ESAT-6/CFP-10 and for virulence of Mycobacterium tuberculosis. Mol Microbiol 2004, 51:359-370.

67. Brodin P, Rosenkrands I, Andersen P, Cole ST, Brosch R: ESAT- 6 proteins: protective antigens and virulence factors? Trends Microbiol 2004, 12:500-508.

68. Gao LY, Guo S, McLaughlin B, Morisaki H, Engel JN, Brown EJ: A mycobacterial virulence gene cluster extending RD1 is required for cytolysis, bacterial spreading and ESAT-6 secretion. Mol Microbiol 2004, 53:1677-1693.

69. de jonge MI, Pehau-Arnaudet G, Fretz MM, Romain F, Bottai D, Brodin P, Honoré N, Marchal G, Jiskoot W, England P, Cole ST, Brosch R: ESAT-6 from Mycobacterium tuberculosis dissociates from its putative chaperone CFP10 under acidic conditions and exhibits membrane-lysing activity. $J$ Bacteriol 2007, 189:6028-6034.

70. Derrick SC, Morris SL: The ESAT6 protein of Mycobacterium tuberculosis induces apoptosis of macrophages by activating caspase expression. Cell Microbiol 2007, 9:1547-1555.

71. Fenton MJ, Vermeulen MW: Immunopathology of tuberculosis: roles of macrophages and monocytes. Infect Immun 1996, 64:683-690.

72. Bermudez LE, Danelishvili L, Early J: Mycobacteria and macrophage apoptosis: complex struggle for survival. Microbe 2006, 1:372-375.

73. Bodnar KA, Serbina NV, Flynn JL: Fate of Mycobacterium tuberculosis within murine dendritic cells. Infect Immun 2001, 69:800-809.

74. Gonzalez-Juarrero M, Turner OC, Turner J, Marietta P, Brooks JV, Orme IM: Temporal and spatial arrangement of lymphocytes within lung granulomas induced by aerosol infection with Mycobacterium tuberculosis. Infect Immun 2001, 69:1722-1728.

75. Russell DG: Who puts the tubercle in tuberculosis? Nat Rev Microbiol 2007, 5:39-47.

76. Wolf AJ, Desvignes L, Linas B, Banaiee N, Tamura T, Takatsu K, Ernst JD: Initiation of the adaptive immune response to Mycobacterium tuberculosis depends on antigen production in the local lymph node, not the lungs. J Exp Med 2008, 205:105-115.

77. Volkman HE, Pozos TC, Zheng J, Davis JM, Rawls JF, Ramakrishnan L: Tuberculous granuloma induction via interaction of a bacterial secreted protein with host epithelium. Science 2010, 327:466-469.

78. Young DB, Gideon HP, Wilkinson RJ: Eliminating latent tuberculosis. Trends Microbiol 2009, 17:193-198.

79. Lin PL, Rodgers M, Smith L, Bigbee M, Myers A, Bigbee C, Chiosea I, Capuano SV, Fuhrman C, Klein E, Flynn JL: Quantitative comparison of active and latent tuberculosis in the cynomolgus macaque model. Infect Immun 2009, 77:4631-4642.

80. Barry CE, Boshoff HI, Dartois V, Dick T, Ehrt S, Flynn J, Schnappinger D, Wilkinson RJ, Young D: The spectrum of latent tuberculosis: rethinking the biology and intervention strategies. Nat Rev Microbiol 2009, 7:845-855.
81. Via LE, Lin PL, Ray SM, Allen SS, Eum SY, Taylor K, Klein E, Manjunatha U, Gonzales J, Lee EG, Park SK, Raleigh JA, Cho SN, McMurray DN, Flynn JL, Barry CE: Tuberculous granulomas are hypoxic in guinea pigs, rabbits and nonhuman primates. Infect Immun 2008, 76:2333-2340.

82. Liew FY, Xu D, Brint EK, O'Neill LA: Negative regulation of toll-like receptor-mediated immune responses. Nat Rev Immunol 2005, 5:446-458.

83. Rothlin CV, Ghosh S, Zuniga El, Oldstone MB, Lemke G: TAM receptors are pleiotropic inhibitors of the innate immune response. Cell 2007 131:1124-1135.

84. Shiloh MU, Manzanillo P, Cox JS: Mycobacterium tuberculosis senses hostderived carbon monoxide during macrophage infection. Cell Host Microbe 2008, 3:323-330.

85. Kumar A, Deshane JS, Crossman DK, Bolisetty S, Yan BS, Kramnik I, Agarwal A, Steyn AJ: Heme oxygenase-1-derived carbon monoxide induces the Mycobacterium tuberculosis dormancy regulon. J Biol Chem 2008, 283:18032-18039.

86. Rustad TR, Sherrid AM, Minch KJ, Sherman DR: Hypoxia: a window into Mycobacterium tuberculosis latency. Cell Microbiol 2009, 11:1151-1159.

87. Shiloh MU, DiGiuseppe Champion PA: To catch a killer. What can mycobacterial models teach us about Mycobacterium tuberculosis pathogenesis. Curr Opin Microbiol 2010, 13:86-92.

88. Nigou J, Zella-Rieser C, Gilleron M, Thurnher M, Puzo G: Mannosylated lipoarabinomannans inhibit IL-12 production by human dendritic cells: evidence for a negative signal delivered through the mannose receptor. $\mathrm{J}$ Immunol 2001, 166:7477-7485.

89. Tobian AAR, Potter NS, Ramachandra L, Pai RK, Convery M, Boom WH, Harding CV: Alternate class I MHC antigen processing is inhibited by Toll-like receptor signaling pathogen-associated molecular patterns Mycobacterium tuberculosis 19-kDa lipoprotein, CpG DNA, and lipopolysaccharide. J Immunol 2003, 171:1413-1422.

90. Pai RK, Pennini ME, Tobian AA, Canaday DH, Boom WH, Harding CV: Prolonged toll-like receptor signaling by Mycobacterium tuberculosis ant its 19-kilodalton lipoprotein inhibits gamma-interferon-induced regulation of selected genes in macrophages. Infect Immun 2004, 72:6603-6614.

91. Briken V, Porcelli S, Besra GS, Kremer L: Mycobacterial lipoarabinomannan and related lipoglycans: from biogenesis to modulation of the immune response. Mol Microbiol 2004, 53:391-403.

92. Kang PB, Azad AK, Torrelles JB, Kaufman TM, Beharka A, Tibesar E, DesJardin LE, Schlesinger LS: The human macrophage mannose receptor directs Mycobacterium tuberculosis lipoarabinomannan-mediated phagosome biogenesis. J Exp Med 2005, 202:987-999.

93. Axelrod S, Oschkinat H, Enders J, Schlegel B, Brinkmann V, Kaufmann SHE, Haas A, Schaible UE: Delay of phagosome maturation by a mycobacterial lipid is reversed by nitric oxide. Cell Microbiol 2008, 10:1530-1545.

94. Kan-Sutton C, Jagannath C, Hunter RL Jr: Trehalose 6,6'-dimycolate on the surface of Mycobacterium tuberculosis modulates surface marker expression for antigen presentation and costimulation in murine macrophages. Microb Infect 2009, 11:40-48.

95. Bowdish DM, Sakamoto K, Kim MJ, Kroos M, Mukhopadhyay S, Leifer CA Tryggvason K, Gordon S, Russell DG: MARCO, TLR2, and CD14 are required for macrophage cytokine responses to mycobacterial trehalose dimycolate and Mycobacterium tuberculosis. PLoS Pathog 2009, 5: e1000474.

96. Baena A, Porcelli SA: Evasion and subversion of antigen presentation by Mycobacterium tuberculosis. Tissue Antigens 2009, 74:189-204.

97. Chang ST, Linderman JJ, Kirschner DE: Multiple mechanisms allow Mycobacterium tuberculosis to continuously inhibit MHC class II-mediated antigen presentation by macrophages. Proc Natl Acad Sci USA 2005, 102:4530-4535.

98. Ohno H, Zhu G, Mohan VP, Chu D, Kohno S, Jacobs WR Jr, Chan J: The effects of reactive nitrogen intermediates on gene expression in Mycobacterium tuberculosis. Cell Microbiol 2003, 5:637-648.

99. Voskuil Ml, Schnappinger D, Visconti KC, Harrell Ml, Dolganov GM, Sherman DR, Schoolnik GK: Inhibition of respiration by nitric oxide induces a Mycobactrium tuberculosis dormancy program. J Exp Med 2003, 198:705-713

100. Betts JC, Lukey PT, Robb LC, McAdam RA, Duncan K: Evaluation of a nutrient starvation model of Mycobacterium tuberculosis persistence by gene and protein expression profiling. Mol Microbiol 2002, 43:717-731. 
101. Lin MY, Ottenhoff TH: Not to wake a sleeping giant: New insights into host-pathogen interactions identify new targets for vaccination against latent Mycobacterium tuberculosis infection. Biol Chem 2008, 389:497-511.

102. Ghosh J, Larsson P, Singh B, Pettersson BM, Islam NM, Sarkar SN, Dasgupta S, Krisebom LA: Sporulation in mycobacteria. Proc Natl Acad Sci USA 2009, 106:10781-10786.

103. Purdy GE, Niederweis M, Russell DG: Decreased outer membrane permeability protects mycobacteria from killing by ubiquitin-derived peptides. Mol Microbiol 2009, 73:844-857.

104. Dye C, Scheele S, Dolin P, Pathania V, Raviglione MC: Consensus statement. Global burden of tuberculosis: estimated incidence, prevalence, and mortality by country. WHO Global Surveillance and Monitoring Project. JAMA 1999, 282:677-686.

105. Wells CD, Cegielski JP, Nelson LJ, Laserson KF, Holtz TH, Finlay A, Castro KG, Weyer K: HIV infection and multidrug-resistant tuberculosis-the perfect storm. J Infect Dis 2007, 196(Suppl 1):S86-S107.

106. Hett EC, Chao MC, Steyn AJ, Fortune SM, Deng LL, Rubin EJ: A partner for the resuscitation-promoting factors of Mycobacterium tuberculosis. Mol Microbiol 2007, 66:658-668.

107. Kana BD, Gordhan BG, Downing KJ, Sung N, Vostroktunova G, Machowski EE, Tsenova L, Young M, Keprelyants A, Kaplan G, Mizrahi V: The resuscitation-promoting factors of Mycobacterium tuberculosis are required for virulence and resuscitation from dormancy but are collectively dispensable for growth in vitro. Mol Microbiol 2008, 67:672-684.

108. Russell-Goldman E, Xu J, Wang X, Chan J, Tufariello JM: A Mycobacterium tuberculosis Rpf double-knockout strain exhibits profound defects in reactivation from chronic tuberculosis and innate immunity phenotypes. Infect Immun 2008, 76:4269-4281.

109. Sutherland I: Recent studies in the epidemiology of tuberculosis, based on risk of being infected with tubercle bacilli. Adv Tuberc Res 1976, 19:1-63.

110. Lillebaek T, Dirksen A, Baess I, Strunge B, Thomsen VO, Andersen AB: Molecular evidence of endogenous reactivation of Mycobacterium tuberculosis after 33 years of latent infection. J Infect Dis 2002, 185:401-404.

111. Ulrichs T, Kaufmann SH: New insights into the function of granulomas in human tuberculosis. J Pathol 2006, 208:261-269.

112. Gutierrez MG, Master SS, Singh SB, Taylor GA, Colombo Ml, Deretic V: Autophagy is a defense mechanism inhibiting BCG and Mycobacterium tuberculosis survival in infected macrophages. Cell 2004, 119:753-766.

113. Comstock GW, Livesay VT, Woolpert SF: The prognosis of a positive tuberculin reaction in childhood and adolescence. Am J Epidemiol 1974, 99:131-138.

114. Ahmad S, Mokaddas E: The occurrence of rare rpoB mutations in rifampicin-resistant Mycobacterium tuberculosis isolates from Kuwait. Int J Antimicrob Agents 2005, 26:205-212.

115. Cardona PJ: A dynamic reinfection hypothesis of latent tuberculosis infection. Infection 2009, 37:80-86.

116. Cardona PJ: New insights on the nature of latent tuberculosis infection and its treatment. Inflamm Allergy Drug Targets 2007, 6:27-39.

117. van der Wel N, Hava D, Houben D, Fluitsma D, van Zon M, Pierson J, Brenner M, Peters PJ: M. tuberculosis and M. leprae translocate from the phagolysosome to the cytosol in myeloid cells. Cell 2007, 129:1287-1298.

118. Peyron P, Vaubourgeix J, Poquet $Y$, Levillain F, Botanch C, Bardou F, Daffé M, Emile JF, Marchou B, Cardona PJ, de Chastellier C, Altare F: Foamy macrophages from tuberculous patients granulomas constitute a nutrient-rich reservoir for $M$. tuberculosis persistence. PLoS Pathog 2008, 4:e1000204.

119. Caceres N, Tapia G, Ojanguren I, Altare F, Gil O, Pinto S, Vilaplana C, Cardona PJ: Evolution of foamy macrophages in the pulmonary granulomas of experimental tuberculosis models. Tuberculosis 2009, 89:175-182.

120. Garton NJ, Christensen H, Minnikin DE, Minnikin DE, Adegbola RA, Barer MR: Intracellular lipophilic inclusions of mycobacteria in vitro and in sputum. Microbiology 2002, 148:2951-2958.

121. Cardona PJ, Llatjos R, Gordillo S, Díaz J, Ojanguren I, Ariza A, Ausina V: Evolution of granulomas in mice infected aerogenically with Mycobacterium tuberculosis. Scand J Immunol 2000, 52:156-163.

122. Wiker HG, Mustafa T, Bjune GA, Harboe M: Evidence for waning of latency in a cohort study of tuberculosis. BMC Infect Dis 2010, 10:37.
123. Mack U, Migliori GB, Sester M, Rieder HL, Ehlers $S$, Goletti D, Bossink A Magdorf K, Holscher C, Kampmann B, Arend SM, Detjen A, Bothamley G Zellweger JP, Milburn H, Diel R, Ravn P, Cobelens F, Cardona PJ, Kan B, Solovic I, Duarte R, Cirillo DM, Lange C, for the TBNET: LTBI: latent tuberculosis infection or lasting immune responses to $M$. tuberculosis? A TBNET consensus statement. Eur Resp J 2009, 33:956-973.

124. Lalvani A, Pareek M: A 100 year update on diagnosis of tuberculosis infection. Br Med Bull 2010, 93:69-84.

125. Pai M, O'Brien R: New diagnostics for latent and active tuberculosis: state of the art and future prospects. Semin Respir Crit Care Med 2008, 29:560-568.

126. Pai M, Zwerling A, Menzies D: T-cell-based assays for the diagnosis of latent tuberculosis infection: an update. Ann Intern Med 2008, 149:177-184

127. Huebner RE, Schein MF, Bass JB Jr: The tuberculin skin test. Clin Infect Dis 1993, 17:976-975.

128. American Thoracic Society, Centers for Disease Control and Prevention: Targeted tuberculin testing and treatment of latent tuberculosis infection. Am J Respir Crit Care Med 2000, 161:S221-S247.

129. Farhat M, Greenaway C, Pai M, Menzies D: False-positive tuberculin skin tests: what is the absolute effect of BCG and nontuberculous mycobacteria. Int J Tuberc Lung Dis 2006, 10:1192-1204.

130. Wang L, Turner MO, Elwood RK, Schulzer M, FitzGerald JM: A meta-analysis of the effect of Bacillus Calmette Guerin vaccination on tuberculin skin test measurements. Thorax 2002, 57:804-809.

131. van Pinxteren LA, Ravn P, Agger EM, Pollock J, Andersen P: Diagnosis of tuberculosis based on the two specific antigens ESAT-6 and CFP10. Clin Diagn Lab Immunol 2000, 7:155-160

132. Arend SM, Franken WP, Aggerbeck H, Prins C, van Dissel JT, ThierryCarstensen B, Tingskov PN, Weldingh K, Andersen P: Double-blind randomized Phase I study comparing rdESAT-6 to tuberculin as skin test reagent in the diagnosis of tuberculosis infection. Tuberculosis 2008, 88:249-261.

133. Wu X, Zhang L, Zhang J, Zhang C, Zhu L, Shi Y: Recombinant early secreted antigen target 6 protein as a skin test antigen for the specific detection of Mycobacterium tuberculosis infection. Clin Exp Immunol 2008, 152:81-87.

134. Weldingh K, Andersen P: ESAT-6/CFP10 skin test predicts disease in $M$. tuberculosis-infected guinea pigs. PLoS One 2008, 3:e1978.

135. Andersen P, Munk ME, Pollock JM, Doherty TM: Specific immune-based diagnosis of tuberculosis. Lancet 2000, 356:1099-1104.

136. Arend SM, Engelhard ACF, Groot G, De Boer K, Andersen P, Ottenhoff THM, van Dissel JT: Tuberculin skin testing compared with T-cell responses to Mycobacterium tuberculosis-specific and nonspecific antigens for detection of latent infection in persons with recent tuberculosis contact. Clin Diagn Lab Immunol 2001, 8:1089-1096.

137. Brock I, Munk ME, Kok-Jensen A, Andersen P: Performance of whole blood IFN-gamma test for tuberculosis diagnosis based on PPD or the specific antigens ESAT-6 and CFP-10. Int J Tuberc Lung Dis 2001, 5:462-467.

138. Lalvani A: Spotting latent infection: the path to tuberculosis control. Thorax 2003, 58:916-918.

139. Pai M, Riley LW, Colford JM Jr: Interferon- $\gamma$ assays in the immunodiagnosis of tuberculosis: a systematic review. Lancet Infect Dis 2004, 4:761-776.

140. Whalen CC: Diagnosis of latent tuberculosis infection: measure for measure. JAMA 2005, 293:2785-2787.

141. Mazurek GH, Villarino ME, CDC: Guidelines for using the QuantiFERON-TB test for diagnosing latent Mycobacterium tuberculosis infection. Centers for Disease Control and Prevention. M M W R Recomm Rep 2003, 52(RR2):15-18

142. Lalvani A: Diagnosing tuberculosis infection in the 21st century: new tools to tackle an old enemy. Chest 2007, 131:1898-1906.

143. Menzies D, Pai M, Comstock G: Meta-analysis: new tests for the diagnosis of latent tuberculosis infection: areas of uncertainty and recommendations for research. Ann Intern Med 2007, 146:340-354.

144. Pai M, Minion J, Steingart K, Ramsay A: New and improved tuberculosis diagnostics: evidence, policy, practice, and impact. Curr Opin Pulm Med 2010, 16:271-284.

145. Mazurek $G H$, Jereb J, Lobue $P$, lademarco MF, Metchock $B$, Vernon A: Guidelines for using the QuantiFERON-TB Gold test for detecting Mycobacterium tuberculosis infection, United States. MMWR Recomm Rep 2005, 54(RR-15):49-55. 
146. National Collaborating Centre for Chronic Conditions: Tuberculosis: clinical diagnosis and management of tuberculosis, and measures for its prevention and control. London, UK: Royal College of Physicians; 2006.

147. Jafari C, Thijsen S, Sotgiu G, Goletti D, Benítez JA, Losi M, Eberhardt R, Kirsten D, Kalsdorf B, Bossink A, Latorre I, Migliori GB, Strassburg A, Winteroll S, Greinert U, Richeldi L, Ernst M, Lange C, Tuberculosis Network European Trialsgroup: Bronchoalveolar lavage enzyme-linked immunospot for a rapid diagnosis of tuberculosis: a Tuberculosis Network European Trialsgroup study. Am J Respir Crit Care Med 2009, 180:666-673

148. Strassburg A, Jafari C, Ernst M, Lotz W, Lange C: Rapid diagnosis of pulmonary TB by BAL enzyme-linked immunospot assay in an immunocompromised host. Eur Respir J 2008, 31:1132-1135.

149. Kim SH, Chu K, Choi SJ, Song KH, Kim HB, Kim NJ, Park SH, Yoon BW, Oh MD, Choe KW: Diagnosis of central nervous system tuberculosis by Tcell-based assays on peripheral blood and cerebrospinal fluid mononuclear cells. Clin Vaccine Immunol 2008, 15:1356-1362.

150. van Zyl-Smit RN, Zwerling A, Dheda K, Pai M: Within-subject variability of interferon-g assay results for tuberculosis and boosting effect of tuberculin skin testing: a systematic review. PLoS One 2009, 4:e8517.

151. Jasmer RM, Nahid P, Hopewell PC: Latent tuberculosis infection. $N$ Engl J Med 2003, 347:1860-1866.

152. Abal AT, Ahmad S, Mokaddas E: Variations in the occurrence of the S315T mutation within the katG gene in isoniazid-resistant clinical Mycobacterium tuberculosis isolates from Kuwait. Microb Drug Resist 2002, 8:99-105.

153. Ahmad S, Mokaddas E, Fares E: Characterization of rpoB mutations in rifampin-resistant clinical Mycobacterium tuberculosis isolates from Kuwait and Dubai. Diagn Microbiol Infect Dis 2002, 44:245-252.

154. Ahmad S, Fares E, Araj GF, Chugh TD, Mustafa AS: Prevalence of S315T mutation within the katG gene in isoniazid-resistant clinical Mycobacterium tuberculosis isolates from Dubai and Beirut. Int I Tuberc Lung Dis 2002, 6:920-926.

155. Ahmad S, Mokaddas E: Contribution of AGC to ACC and other mutations at codon 315 of the katG gene in isoniazid-resistant Mycobacterium tuberculosis isolates from the Middle East. Int J Antimicrob Agents 2004 23:473-479.

156. Ahmad S, Jaber A-A, Mokaddas E: Frequency of embB codon 306 mutations in ethambutol-susceptible and -resistant clinical Mycobacterium tuberculosis isolates in Kuwait. Tuberculosis 2007, 87:123-129.

157. Al-Zarouni M, Dash N, Al Ali M, Al-Shehhi F, Panigrahi D: Tuberculosis and MDR-TB in the northern emirates of United Arab Emirates: a 5-year study. Southeast Asian J Trop Med Public Health 2010, 41:163-168.

158. Fuhrmann S, Streitz M, Kern F: How flow cytometry is changing the study of TB immunology and clinical diagnosis. Cytometry A 2008, 73:1100-1106.

159. Ahmad S, Amoudy HA, Thole JE, Young DB, Mustafa AS: Identification of a novel protein antigen encoded by a Mycobacterium tuberculosis-specific RD1 region gene. Scand J Immunol 1999, 49:515-522.

160. Ahmad S, El-Shazly S, Mustafa AS, Al-Attiyah R: Mammalian cell-entry proteins encoded by the mce3 operon of Mycobacterium tuberculosis are expressed during natural infection in humans. Scand J Immunol 2004, 60:382-391.

161. Singh KK, Dong Y, Patibandla SA, McMurray DN, Arora VK, Laal S: Immunogenicity of the Mycobacterium tuberculosis PPE55 (Rv3347c) protein during incipient and clinical tuberculosis. Infect Immun 2005, 73:5004-5014.

162. El-Shazly S, Mustafa AS, Ahmad S, Al-Attiyah R: Utility of three mammalian cell-entry proteins of Mycobacterium tuberculosis in the serodiagnosis of tuberculosis. Int J Tuberc Lung Dis 2007, 11:676-682.

163. Centers for Disease Control and Prevention: Guidelines for the investigation of contacts with infectious tuberculosis: recommendations from the National Tuberculosis Controllers Association and CDC. MMWR Recomm Rep 2005, 54(RR-15):1-47.

164. Blumberg HM, Leonard MK Jr, Jasmer RM: Update on the treatment of tuberculosis and latent tuberculosis infection. JAMA 2005, 293:2776-2784.

165. International Union Against Tuberculosis: Efficacy of various durations of isoniazid preventive therapy for tuberculosis: five years of follow-up in the IUAT trial. Bull World Health Org 1982, 60:555-564.
166. Comstock GW: How much isoniazid is needed for prevention of tuberculosis among immunocompetent adults? Int J Tuberc Lung Dis 1999, 3:847-850.

167. LoBue PA, Moser KS: Use of isoniazid for latent tuberculosis infection in a public health clinic. Am J Respir Crit Care Med 2003, 168:443-447.

168. Horsburg CR Jr: Priorities for the treatment of latent tuberculosis infection in the United States. N Engl J Med 2004, 350:2060-2067.

169. Menzies D, Dion MJ, Rabinovitch B, Mannix S, Brassard P, Schwartzman K: Treatment completion and costs of a randomized trial of rifampin for 4 months versus isoniazid for 9 months. Am J Respir Crit Care Med 2004 170:445-449.

170. Tulsky JP, Pilote L, Hahn JA, Zolopa AJ, Burke M, Chesney M, Moss AR: Adherence to isoniazid prophylaxis in the homeless: a randomized controlled trial. Arch Intern Med 2000, 160:697-702.

171. Byrd RB, Horn BR, Solomon DA, Griggs GA: Toxic effects of isoniazid in tuberculosis chemoprophylaxis: role of biochemical monitoring in 1,000 patients. JAMA 1979, 241:1239-1241.

172. Dickinson DS, Bailey WC, Hirschowitz BJ, Soong SJ, Eidus L, Hodgkin MM: Risk factors for isoniazid (INH)-induced liver dysfunction. J Clin Gastroenterol 1981, 3:271-279.

173. Nolan CM, Goldberg SV, Buskin SE: Hepatotoxicity associated with isoniazid preventive therapy: a 7-year survey from a public health tuberculosis clinic. JAMA 1999, 281:1014-1018.

174. Snider DE Jr: Pyridoxine supplementation during isoniazid therapy. Tubercle 1980, 61:191-196.

175. Polesky A, Farber HW, Gottlieb DJ, Park H, Levinson S, O'Connell JJ, McInnis B, Nieves RL, Bernardo J: Rifampin preventive therapy for tuberculosis in Boston's homeless. Am J Respir Crit Care Med 1996 154:1473-1477.

176. Villarino ME, Ridzon R, Weismuller PC, Elcock M, Maxwell RM, Meador J, Smith PJ, Carson ML, Geiter LJ: Rifampin preventive therapy for tuberculosis infection: experience with 157 adolescents. Am J Respir Crit Care Med 1997, 155:1735-1738.

177. Reichman LB, Lardizabal A, Hayden $\mathrm{CH}$ : Considering the role of four months of rifampin in the treatment of latent tuberculosis infection. Am J Respir Crit Care Med 2004, 170:832-835.

178. Lardizabal A, Passannate M, Kojakali F, Hayden C, Reichman LB: Enhancement of treatment completion for latent tuberculosis infection with 4 months of rifampin. Chest 2006, 130:1712-1717.

179. Page KR, Sifakis F, Montes de Oca R, Cronin WA, Doherty MC, Federline L, Bur S, Walsh T, Karney W, Milman J, Baruch N, Adelakun A, Dorman SE: Improved adherence and less toxicity with rifampin vs isoniazid for the treatment of latent tuberculosis: a retrospective study. Arch Intern Med 2006, 166:1863-1870

180. Menzies D, Long R, Trajman A, Dion MJ, Yang J, Al Jahdali H, Memish Z, Khan K, Gardam M, Hoeppner V, Benedetti A, Schwartzman K: Adverse events with 4 months of rifampin therapy or 9 months of isoniazid therapy for latent tuberculosis infection: a randomized trial. Ann Intern Med 2008, 149:689-697.

181. Nolan CM, Williams DL, Donald Cave M, Eisenach KD, El-Hajj H, Hooton TM, Thompson RL, Goldberg SV: Evolution of rifampin resistance in human immunodeficiency virus-associated tuberculosis. Am J Respir Crit Care Med 1995, 152:1067-1071.

182. Sandman L, Schluger NW, Davidow AL, Bonk S: Risk factors for rifampinmonoresistant tuberculosis: a case-control study. Am J Respir Crit Care Med 1999, 159:468-472.

183. Perlman DC, El Sadr WM, Nelson ET, Matts JP, Telzak EE, Salomon N Chirgwin K, Hafner R: Variation of chest radiographic patterns in pulmonary tuberculosis by degree of human immunodeficiency virusrelated immunosuppression. Clin Infect Dis 1997, 25:242-246.

184. Crampin AC, Floyd S, Mwanungulu F, Black G, Ndhlovu R, Mwaiyeghele E, Glynn JR, Warndorff DK, Fine PE: Comparison of two versus three smears in identifying culture-positive tuberculosis patients in a rural African setting with high HIV prevalence. Int J Tuberc Lung Dis 2001, 5:994-999.

185. Kimerling ME, Phillips P, Patterson P, Hall M, Robinson CA, Dunlap NE: Low serum antimycobacterial drug levels in non-HIV-infected tuberculosis patients. Chest 1998, 113:1178-1183.

186. Mokaddas E, Ahmad S, Abal AT, Al-Shami AS: Molecular fingerprinting reveals familial transmission of rifampin-resistant tuberculosis in Kuwait. Ann Saudi Med 2005, 25:150-153. 
187. Halsey NA, Coberly JS, Desormeaux J, Losikoff P, Atkinson J, Moulton LH, Contave M, Johnson M, Davis H, Geiter L, Johnson E, Huebner R, Boulos R, Chaisson RE: Randomized trial of isoniazid versus rifampicin and pyrazinamide for prevention of tuberculosis in HIV-1 infection. Lancet 1998, 351:678-792.

188. Gordin F, Chaisson RE, Matts JP, Miller C, de Lourdes Garcia M, Hafner R, Valdespino JL, Coberly J, Schechter M, Klukowicz AJ, Barry MA, O'Brien RJ, Terry Bairn Community Programs for Clinical Research on AIDS, the Adult AIDS Clinical Trials Group, the Pan American Health Organization, and the Centers for Disease Control and Prevention Study Group: Rifampin and pyrazinamide vs isoniazid for prevention of tuberculosis in HIV-infected persons. JAMA 2000, 283:1445-1450.

189. Centers for Disease Control and Prevention: Update: adverse event data and revised American Thoracic Society/CDC recommendations against the use of rifampin and pyrazinamide for treatment of latent tuberculosis infection-United States, 2003. MMWR Morb Mortal Wkly Rep 2003, 52:735-739.

190. Gao X-F, Wang L, Liu G-L, Wen J, Sun X, Xie Y, Li Y-P: Rifampicin plus pyrazinamide versus isoniazid for treating latent tuberculosis infection: a meta analysis. Int J Tuberc Lung Dis 2006, 10:1080-1090.

191. Gordin FM, Cohn DL, Matts JP, Chaisson RE, O'Brien RJ, Terry Beirn Community Programs for Clinical Research on AIDS; Adult AIDS Clinical Trials Group, Centers for Disease Control and Prevention: Hepatotoxicity of rifampin and pyrazinamide in the treatment of latent tuberculosis infection in HIV-infected persons: is it different than in HIV-uninfected persons? Clin Infect Dis 2004, 39:561-565.

192. Tortajada C, Martinez-Lacasa J, Sanchez F, Jimenez-Fuentes A, De Souza ML, Garcia JF, Martinez JA, Cayla JA: Is the combination of pyrazinamide plus rifampicin safe for treating latent tuberculosis infection in persons not infected with the human immunodeficiency virus? Int J Tuberc Lung Dis 2005, 9:276-281.

193. Ena J, Valls V: Short-course therapy with rifampin and isoniazid for latent tuberculosis infection: a meta analysis. Clin Infect Dis 2005, 40:670-676.

194. Spyridis NP, Spyridis PG, Gelesme A, Sypsa V, Valianatou M, Metsou F, Gourgiotis D, Tsolia MN: The effectiveness of isoniazid alone versus 3and 4-month regimens of isoniazid plus rifampin for treatment of latent tuberculosis infection in children: results of an 11-year randomized study. Clin Infect Dis 2006, 45:715-722.

195. Rennie TW, Bothamley GH, Engova D, Bates IP: Patient choice promotes adherence in preventive treatment for latent tuberculosis. Eur Respir $J$ 2007, 30:728-735.

196. Weiner M, Bock N, Peloquin CA, Burman WJ, Khan A, Vernon A, Zhao Z, Weis S, Sterling TR, Hayden K, Goldberg S, Tuberculosis Trials Consortium: Pharmacokinetics of rifapentine at 600,900 and 1,200 mg during once weekly tuberculosis therapy. Am J Respir Crit Care Med 2004, 169:1191-1197.

197. Schechter M, Zajdenverg R, Falco G, Barnes GL, Faulhaber JC, Coberly JS, Moore RD, Chaisson RE: Weekly rifapentine/isoniazid or daily rifampin/ pyrazinamide for latent tuberculosis in household contacts. Am J Respir Crit Care Med 2006, 173:922-926.

198. Fraser A, Paul M, Attamna A, Leibovici L: Treatment of latent tuberculosis in persons at risk for multidrug-resistant tuberculosis: systematic review. Int J Tuberc Lung Dis 2006, 10:19-23.

199. Ridzon R, Meador J, Maxwell R, Higgins K, Weismuller P, Onorato IM: Asymptomatic hepatitis in persons who received alternative preventive therapy with pyrazinamide and ofloxacin. Clin Infect Dis 1997, 24:1264-1265

200. Nuermberger EL, Yoshimatsu T, Tyagi S, O'Brien RJ, Vernon AN, Chaisson RE, Bishai WR, Grosset $\mathrm{JH}$ : Moxifloxacin-containing regimen greatly reduces time to culture conversion in murine tuberculosis. Am J Respir Crit Care Med 2004, 169:421-426.

201. Rustomjee R, Lienhardt C, Kanyok T, Davies GR, Levin J, Mthiyane T, Reddy C, Sturm AW, Sirgel FA, Allen J, Coleman DJ, Fourie B, Mitchison DA, Gatifloxacin for TB (OFLOTUB) study team: A phase II study of the sterilizing activities of ofloxacin, gatifloxacin and moxifloxacin in pulmonary tuberculosis. Int J Tuberc Lung Dis 2008, 12:128-138.

202. Nuermberger E, Tyagi S, Williams KN, Rosenthal I, Bishai WR, Grosset JH: Rifapentine, moxifloxacin, or DNA vaccine improves treatment of latent tuberculosis in a mouse model. Am J Respir Crit Care Med 2005, 172:1452-1456.
203. Nuermberger E, Tyagi S, Tasneen R, Williams KN, Almeida D, Rosenthal I, Grosset JH: Powerful bactericidal and sterilizing activity of a regimen containing PA-824, moxifloxacin and pyrazinamide in a murine model of tuberculosis. Antimicrob Agents Chemother 2008, 52:1522-1524.

204. Matsumoto M, Hashizume $H$, Tomishige $T$, Kawasaki M, Tsubouchi $H$, Sasaki H, Shimokawa Y, Komatsu M: OPC-67683, a nitro-dihydroimidazooxazole derivative with promising action against tuberculosis in vitro and in mice. PLos Med 2006, 3:e466.

205. Andries K, Verhasselt $P$, Guillemont J, Göhlmann HW, Neefs JM, Winkler H, Van Gestel J, Timmerman P, Zhu M, Lee E, Williams P, de Chaffoy D, Huitric E, Hoffner S, Cambau E, Truffot-Pernot C, Lounis N, Jarlier V: A diarylquinoline drug active on the ATP synthase of Mycobacterium tuberculosis. Science 2005, 307:223-227.

206. Lounis N, Veziris N, Chauffour A, Truffot-Pernot C, Andries K, Jarlier V: Combinations of R207910 with drugs used to treat multidrug-resistant tuberculosis have the potential to shorten treatment duration. Antimicrob Agents Chemother 2006, 50:3543-3547.

207. Protopopova M, Hanrahan C, Nikonenko B, Samala R, Chen P, Gearhart J, Einck L, Nacy CA: Identification of a new antitubercular drug candidate, SQ109, from a combinatorial library of 1,2-ethylenediamines. J Antimicrob Chemother 2005, 56:968-974.

208. Nikonenko BV, Protopopova MN, Samala R, Einck L, Nacy CA: Drug therapy of experimental TB: improved outcome by combining SQ109, a new diamine antibiotic with existing TB drugs. Antimicrob Agents Chemother 2007, 51:1563-1565.

209. Kaufmann SHE: Future vaccination strategies against tuberculosis: thinking outside the box. Immunity 2010, 33:567-577.

210. Kaufmann SH, Hussey G, Lambert PH: New vaccines for tuberculosis. Lancet 2010, 375:2110-2119.

211. Parida SK, Kaufmann SHE: Novel tuberculosis vaccines on the horizon Curr Opin Immunol 2010, 22:374-384.

212. Grode L, Seiler P, Baumann S, Hess J, Brinkman V, Nasse Eddin A, Mann P, Goosmann C, Bandermann S, Smith D, Bancroft GJ, Reyrat JM, van Soolingen D, Raupach B, Kaufmann SH: Increased vaccine efficacy against tuberculosis of recombinant Mycobacterium bovis bacille CalmetteGuerrin mutants that secrete listeriolysin. J Clin Invest 2005, 115:2472-2479.

213. Tullius MV, Harth G, Maslesa-Galic S, Dillon BJ, Horwitz MA: A replicationlimited recombinant Mycobacterium bovis BCG vaccine against tuberculosis designed for human immunodeficiency virus-positive persons is safer and more efficacious than BCG. Infect Immun 2008, 76:5200-5214.

214. Sander CR, Pathan AA, Beveridge NE, Poulton I, Minassian A, Adler N, Van Wijgerden J, Hill AV, Gleeson FV, Davies RJ, Pasvol G, McShane H: Safety and immunogenicity of a new tuberculosis vaccine MVA85A in Mycobacterium tuberculosis-infected individuals. Am J Respir Crit Care Med 2009, 179:724-733

215. Reed SG, Bertholet S, Coler RN, Friede M: New horizons in adjuvants for vaccine development. Trends Immunol 2009, 30:23-32.

216. van Dissel JT, Arend SM, Prins C, Bang P, Tingskov PN, Lingnau K, Nouta J, Klein MR, Rosenkrands I, Ottenhoff TH, Kromann I, Doherty TM, Andersen P: Ag85B-ESAT-6 adjuvanted with IC31 promotes strong and long-lived Mycobacterium tuberculosis specific T cell responses in naïve human volunteers. Vaccine 2010, 28:3571-3581.

doi:10.1186/1465-9921-11-169

Cite this article as: Ahmad: New approaches in the diagnosis and treatment of latent tuberculosis infection. Respiratory Research 2010 11:169. 